\begin{tabular}{|c|ccc|}
\hline Received & Reviewed & Published & Doi Number \\
\hline 18.04 .2019 & 04.06 .2019 & 30.06 .2019 & $10.18298 /$ ijlet.23362 \\
\hline
\end{tabular}
Analysis of Reading Texts in Turkish Course Books for Foreigners in the Context of Text Types, Originality of Texts and Inclusion of Cultural Elements: The Example of Istanbul Course Book Pack for Foreigners

Ümit YILDIZ ${ }^{1} \&$ Gülsüm SERTOĞLU ${ }^{2} \&$ Afra Nur DEMIROK ${ }^{3}$ \& İbrahim KİRL $\dot{I}^{4}$

\begin{abstract}
In this study, the reading texts in İstanbul Course Book Pack for Foreigners were analyzed in terms of text types, originality/characteristics and inclusion of cultural elements. These dimensions were analyzed by using document analysis technique. The data collection process started with the identification of the reading texts in the İstanbul Course Book Pack for Foreigners (B1, B2, C1+). The identified texts were classified according to their types. Text originality/property case was been identified and divided into categories under the headlines of "original text" and "custom text". In the last stage, the inclusion level of the cultural elements in the reading texts in İstanbul Course Book Pack for Foreigners (B1, B2, C1+) was determined. According to the results of the study; it is determined that the reading texts in Turkish textbooks prepared for foreigners, in terms of text types, mostly contain informative texts. In terms of originality dimension the course books contain more specific texts. Besides, they do not include cultural elements sufficiently. The distribution of the text types to the B1, B2, C1+ levels was disproportionate. In terms of the informative text types, the articles were mostly included in the course books while for the narrative text types little space was given. The poetic text types were not included.
\end{abstract}

Key Words: Teaching Turkish to Foreigners, textbooks, Istanbul Course Book Pack for Foreigners, text type, originality, cultural elements.

\title{
Yabancılar için Türkçe Ders Kitaplarındaki Okuma Metinlerinin; Metin Türü, Metinlerin Özgünlüğü ve Metinlerde Geçen Kültür Ögeleri Bağlamında İncelenmesi: İstanbul Seti Örneği
}

\begin{abstract}
ÖZET
Bu çalışmada, “İstanbul Yabancılar İçin Türkçe Seti”nde yer alan okuma metinlerinin; türleri, özgünlük/özellik durumları ve kültürel ögeleri içerme oranları üzerinde durulmuştur. Boyutlar, “İstanbul Yabancılar İçin Türkçe Seti” B1, B2, C1+ düzeyi ders kitapları esas alınarak doküman incelemesi tekniğiyle analiz edilmiştir. Veri toplama sürecinde, ilk aşamada "İstanbul Yabancılar İçin Türkçe Seti"ndeki (B1, B2, C1+) okuma metinleri tespit edilmiş, metinler türlerine göre sınıflandırılmıştır. Metinlerin özgünlük/özellik durumları belirlenmiş ve "özgün metin”, "özel metin” başlıkları altında kategorilere ayrılmıştır. Son aşamada, "İstanbul Yabancılar İçin Türkçe Seti"ndeki (B1, B2, C1+) okuma metinlerinin kültürel ögeleri içerme düzeyleri belirlenmeye çalışılmıştır. Araştırmadan elde edilen sonuçlara göre; yabancılar için hazırlanan Türkçe ders kitaplarındaki okuma metinlerinin çoğunlukla bilgilendirici ve özel metinleri içerdiği, kültürel ögeleri ise yeterince içermediği tespit edilmiştir. Diğer taraftan, metin türlerinin B1, B2, C1+ düzeylerine dağılımının orantısız olduğu, bilgilendirici türlerden en çok makaleye yer verilirken hikâye edici türlere çok az yer verildiği, şiirsel türlere ise yer verilmediği görülmüştür.
\end{abstract}

Anahtar Kelimeler: Yabancılara Türkçe Öğretimi, ders kitapları, İstanbul Yabancılar İçin Türkçe Seti, metin türü, özgünlük, kültürel ögeler.

\footnotetext{
${ }^{1}$ Doçent Doktor, Akdeniz Üniversitesi, umityildiz@akdeniz.edu.tr

2 Yüksek Lisans Öğrencisi, Akdeniz Üniversitesi, gulsumsertogluu@gmail.com

3 Yüksek Lisans Öğrencisi, Akdeniz Üniversitesi, afranurdemirok@gmail.com

${ }^{4}$ Yüksek Lisans Öğrencisi, Akdeniz Üniversitesi, ibrahim.kirli.1994@gmail.com
} 


\section{Giriş}

Kitap, "ciltli ve ciltsiz olarak bir araya getirilmiş, basılı veya yazılı kâğıt yaprakların bütünüdür" (TDK, 2019). Ders kitapları ise bir eğitim programını oluşturan hedef, içerik, öğretim durumları ve ölçme değerlendirme boyutlarına uygun oluşturulmuş basılı öğretim materyalleri olarak kabul edilebilir (Demirel ve Kıroğlu, 2008).

Geçmişten günümüze birçok alanda eğitime/öğretime fayda sağlayan ve derslerde ana materyal olarak kullanılan ders kitapları, yabancı dil olarak Türkçe öğretiminde de eğitim-öğretim sürecinde kullanılan materyallerin başında gelmektedir. Kaliteli bir ders kitabı eğitim-öğretim sürecinin olmazsa olmazlarından biri olarak kabul edilmektedir. Bu sebeple, farklı bakış açılarına ve farklı hedeflere hizmet eden ders kitapları tasarlanmaktadır. Kitaplar genel olarak öğrenci düzeyine uygun okuma metinleri, görsel unsurlar ve etkinliklerden meydana gelmektedir. Buradaki amaç, anlama ve anlatma becerilerini geliştirmek ve hedeflenen kazanımları gerçekleştirmektir (Tok, 2013).

Tertemiz, Ercan ve Kayabaşı (2011), Gagne'nin ortaya attığı fikirlerden yola çıkarak nitelikli bir ders kitabının sahip olması gereken yeterlilikleri aşağıdaki şekilde ifade etmiştir:

- Ders kitapları öğrencilerin konuya karşı ilgilerini artırmalı,

- Konuların amaçlarını açıcça belirtebilmeli,

- Öğrencinin dikkatini dersin önemli bölümlerine çekebilmeli,

- Dersin içeriğinde yer alan önemli bilgileri içermeli,

- Bilginin depolanması boyutunda fayda sağlamalı,

- İçerik boyutunda yeterince örnek ve uygulama barındırmalı,

- Öğrenciyi bilgi ve becerilerini geliştirebilmesi için teşvik etmeli,

- Problemleri anlamayı ve çözmeyi öğrencilere öğretebilmeli,

- Değerlendirme sürecinde öğrencinin kendini değerlendirebilmesine fırsatlar tanıyarak seçenekler sunmalı,

- Benlik, iç kontrol ve çalışma yönlerinden öğrenciyi kendini geliştirmeye sevk etmelidir.

\subsection{Dil ve Kültür İlişkisi}

Aksan'a (2015) göre, kimi zaman dilde yer alan bir kelime; bir milletin inanışları, yaşayış biçimi, kişilerin kendi aralarındaki ilişkileri, somut ve somut olmayan kültürü hakkında bilgi verebilir. Demir ve Açık (2011), bu durumu "Bir milletin özelliklerini en iyi açılayan dildir, hatta toplumun özelikleri dil ile birleşir ve kültürün tam bir yansitıcısı olur. Biri olmadan diğerinin varlığı da düşünülemez. Kültürü aktarmayı sağlayan dildir, kültür ise ortak değerler vasıtasıyla dilin anlatılmasına olanak tanır. Kültür tarihi bir süreçte gelişir ve bunu diğer nesillere aktarabilmenin tek yolu dildir, bundan dolayı dil sayesinde kültürün yapısı bozulmaz ve canlılığı korunur." şeklinde açıklamaktadır. Kırkkeseli'ye (2017) göre, toplumların kültür dünyaları kendilerine özgüdür. Ortak değerler bütünü olan kültür, gelecek nesillere dil ile birlikte aktarılmaktadır. Diğer yandan, birbirinin devamı olan dil ve kültür unsurları, insanlık için önemli bir hazine niteliğindedir.

Milletlerin dili ve kültürü, akan bir nehir gibi; temas ettiği her kültürden birtakım unsurlar alarak bugünkü şekline kavuşmuştur (Kaplan, 1982). 


\subsection{Yabancı Dil Öğretiminde Kültür Aktarımının Önemi}

Yabancı bir dili öğrenmek; o dilin sadece kurallarını, gramer yapılarını öğrenmek değil, aynı zamanda yeni bir kültürle etkileşimde bulunmak, o dilin kültürünü oluşturan ögelerin farkına varmak ve öğrenmektir (Okur ve Keskin, 2013).

Asutay (2003), tüm kültürlerin kendi kimliklerini kazanmasında rol oynayan kendilerine has bir dili olduğunu ve bu nedenle yeni bir dil öğrenmenin yeni bir kültür öğrenmekle eşdeğer olduğunu belirtmektedir. Asutay (2003), ayrıca bu görüşten yola çıkarak dil öğretiminde kültür unsurunun hiçbir zaman göz ardı edilmemesi gerektiğini vurgulamaktadır. Öyle ki, kültür aktarımının olmadığı bir süreçte dilin monoton ve sıkıcı bir hale gelmesi muhtemeldir.

Tomalin ve Stempleski (1993), kültür öğretiminde öğrencilere aktarılacak unsurları yedi başlık altında aşağıdaki gibi toplamıştır:

1. "Öğrencilerin, her insanın davranışında kültürün etkisi olduğunu anlamalarına yardımcı olmak,

2. Öğrencilerin, yaş, cinsiyet, sosyal sınıf gibi değişkenlerin insanların konuşmalarında ve davranışlarında etkisi olduğunu anlamalarına yardımcı olmak,

3. Öğrencilerin, hedef kültürdeki ortak durumlarda gösterilen ortak davranışların farkına varmalarına yardımcı olmak,

4. Öğrencilerin bazı kelime ve cümleciklerin kültürün bir sonucu olarak hep aynı şekilde birbiri ardına geldiğinin farkına varmalarına yardımcı olmak,

5. Öğrencilerin, hedef kültürle ilgili genellemeleri objektif gözle değerlendirmelerine yardımcı olmak,

6. Öğrencilerin, hedef kültürle ilgili bilgi toplama becerilerinin gelişmesine yardımcı olmak,

7. Öğrencilerde, hedef kültürle ilgili merak uyandırmak ve onların o kültürdeki insanlara karşı empati kurmalarını sağlamak." (Tomalin ve Stempleski, 1993, akt. Barışkan, 2010).

Okur ve Keskin'e (2013: 1620) göre, yabancı dil olarak Türkçe öğretimi için hazırlanmış ders kitaplarında yer alan metinlerin seçiminde "kültür aktarımı" ilkesine dikkat edilmesi gerekmektedir. Çünkü kültür aktarımının önem kazandığı günümüz yabancı dil öğretim süreçlerinde, dil öğretim materyallerinin önemli bir ögesi olan ders kitapları da o topluma ait unsurları içinde barındırır. Yabancı dil öğretim süreçlerine yönelik tasarlanmış ders kitaplarında yer alacak metinlerin seçiminin amaçlı bir şekilde yapılması kültür aktarımı süreçlerinde metinleri etkili bir araç kılacaktır.

\subsection{Dil Öğretim Kitaplarında Kullanılan Metinlerin Özellikleri}

Güneş (2017), dil öğretiminde kullanılan metinleri; üretilmiş, özgün, edebî ve otantik olarak dört başlık altında sınıflandırmaktadır (Şekil 1). Diğer taraftan metinleri; bilgilendirici metinler, öyküleyici metinler ve şiirler olarak da gruplandırmak mümkündür. 
Şekil 1. Dil Öğretiminde Kullanılan Metinler

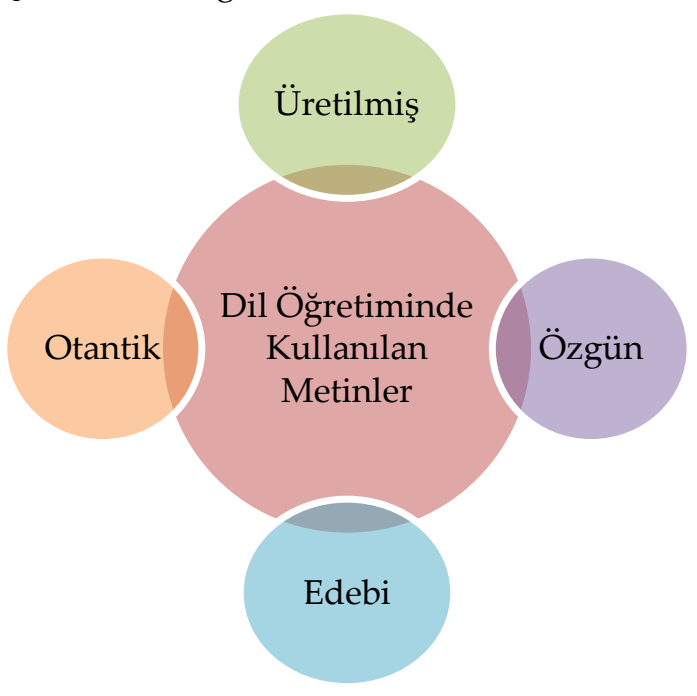

Bu araştırmada, "İstanbul Yabancılar İçin Türkçe Seti"nde yer alan B1, B2, C1+ ders kitaplarındaki okuma metinlerinin; metin türü, metinlerin özgünlük/özellik durumları ve metinlerde geçen kültürel ögeler açısından incelenmesi amaçlanmıştır.

Çalışmada, metin türlerinin belirlenmesinde araştırmacılar tarafından oluşturulan metin türleri tablosu temel alınmıştır. Tablo oluşturulurken ilk etapta ilgili alan yazın taranmış ve metin türleri sınıflandırmaları ile ilgili derleme çalışması yapılmıştır. İkinci etapta, derlenen metin türleri sinıflandırmaları içerisinden MEB Türkçe Dersi Öğretim Programı'ndan (2018), “bilgilendirici metinler, hikâye edici metinler, şiirsel metinler", Avrupa Ortak Başvuru Metni'nden (2015) "metinler ve medya" başlıkları alınarak yeni bir sınıflandırma oluşturulmaya çalışılmıştır. Belirlenen başlıklardan "bilgilendirici metin" başlığı altında MEB'den (2018) "biyografiler, otobiyografiler, anı, dilekçe, efemera ve broşür (liste, diyagram, tablo, grafik, kroki, harita, afiş vb. karma içerikli metinler), günlük, haber metni, kartpostal, kılavuzlar (kullanım kılavuzları, tarifname vb.), gezi yazısı, makale, fıkra (köşe yazısı), söyleşi (sohbet), deneme, mektup, özlü sözler"; Özmen'den (2001) "röportaj"; Avrupa Ortak Başvuru Metni'den (2015) "kamu ilanları ve talimatlar, vaizler ayinler (törenler, resmî dini hizmetler), halka açık münazaralar ve konuşmalar, süpermarket, bakkal, pazar tezgâhlarındaki levhalar, biletler, raporlar" ve "bildiriler" şeklinde türler alınmıştır. "Hikâye edici metinler" başlığı altında MEB'den (2018) "çizgi roman, fabl, hikâye, karikatür, masal, efsane, destan, tiyatro, roman, mizahi fıkra" türleri alınmıştır. "Metinler ve medya" başlığı altında ise MEB'den (2018) “çizgi roman, fabl, hikâye, karikatür, masal, efsane, destan, tiyatro, roman, mizahi fıkra", Avrupa Ortak Başvuru Metni'nden (2015) "haber yayınları, telefon görüşmeleri, spor yorumları (futbol, basketbol, boks, at yarışları, vs.), dersler, sunumlar, veri tabanları (haberler, edebiyat, genel bilgi, vs.)"; MEB'den (2018) "sosyal medya mesajları" türleri alınmıştır. "Şiirsel metinler" başlığı altında MEB'den (2015) "mani, ninni, şarkı, türkü, şiir, tekerleme, sayışmaca, bilmece" başlıkları alınmıştır. MEB (2018), Avrupa Ortak Başvuru Metni (2015) ve Özmen (2001)'in metin türleri sinıflandırmaları temel alınarak oluşturulan örnek sınıflandırmaya ilişkin bilgilere Tablo 1'de yer verilmiştir. 
Tablo 1. Metin Türleri Örnek Sınıflandırması

\begin{tabular}{|c|c|c|c|}
\hline Bilgilendirici Metinler & $\begin{array}{l}\text { Hikâye Edici } \\
\text { Metinler }\end{array}$ & Metinler ve Medya & $\begin{array}{l}\text { Şiirsel } \\
\text { Metinler }\end{array}$ \\
\hline Biyografiler & Çizgi Roman & Sosyal Medya Mesajları & Mani \\
\hline Otobiyografiler & Fabl & Blog yazıları & Ninni \\
\hline Anı & Hikâye & E-posta & Şark1 \\
\hline Dilekçe & Karikatür & Reklam & Türkü \\
\hline $\begin{array}{l}\text { Efemera ve Broşür (liste, diyagram, } \\
\text { tablo, grafik, kroki, harita, afiş vb. } \\
\text { karma içerikli metinler) }\end{array}$ & Masal & Dersler, sunumlar & Şiir \\
\hline Günlük & Efsane & $\begin{array}{l}\text { Spor yorumları (futbol, } \\
\text { basketbol, boks, at yarışları, vs.) }\end{array}$ & Tekerleme \\
\hline \multicolumn{4}{|l|}{ Haber Metni } \\
\hline Kartpostal & Destan & Telefon görüşmeleri & Sayışmaca \\
\hline $\begin{array}{l}\text { Kilavuzlar (kullanım kılavuzları, } \\
\text { tarifname vb.) }\end{array}$ & Tiyatro & Haber yayınları & Bilmece \\
\hline Kamu ilanları ve talimatlar & Roman & $\begin{array}{l}\text { Veri Tabanları (haberler, } \\
\text { edebiyat, genel bilgi, vs.) }\end{array}$ & \\
\hline Gezi Yazısı & Mizahi Fıkra & & \\
\hline \multicolumn{4}{|l|}{ Makale } \\
\hline \multicolumn{4}{|l|}{ F1kra (Köşe Yazısı) } \\
\hline \multicolumn{4}{|l|}{ Söyleşi (Sohbet) } \\
\hline \multicolumn{4}{|l|}{ Deneme } \\
\hline \multicolumn{4}{|l|}{ Röportaj } \\
\hline $\begin{array}{lrr}\text { Mektup } \quad \text { (ticari ve } & \text { mesleki } \\
\text { mektuplar, } & \text { fakslar; } & \text { kişisel } \\
\text { mektuplar) } & & \end{array}$ & & & \\
\hline \multicolumn{4}{|l|}{$\begin{array}{l}\text { Özlü Sözler (vecize, atasözü, } \\
\text { deyim, aforizma, duvar yazıları, } \\
\text { motto, döviz vb.) }\end{array}$} \\
\hline \multicolumn{4}{|l|}{$\begin{array}{l}\text { Vaizler Ayinler (törenler, resmî } \\
\text { dini hizmetler) }\end{array}$} \\
\hline $\begin{array}{l}\text { Halka açık münazaralar ve } \\
\text { konuşmalar }\end{array}$ & & & \\
\hline $\begin{array}{l}\text { Süpermarket, bakkal, pazar } \\
\text { tezgâhlarındaki levhalar }\end{array}$ & & & \\
\hline Biletler & & & \\
\hline Raporlar ve bildiriler & & & \\
\hline
\end{tabular}


Avrupa Ortak Başvuru Metni'nde (AOBM) (2015), yazılı ve sözlü metinlerin belli oranda taşıması gereken "özgünlük" ve "özellik" kavramlarının genel anlamda iki başlık altında toplandığ görülmektedir:

\section{Özgün Metinler}

“Öğrencinin, öğrendiği dili doğrudan kullanarak deneyimleri sonucu karşılaştığı, basitleştirme ve düzeltme gibi işlemlerden geçmemiş günlük gazete, dergiler ve yayınlarda karşılaşılabilecek özgün metinler; Öğrencinin deneyimlerine, ilgilerine ve kişiliğine uygun hale getirilmek üzere, seçilmiş, derecelendirilmiş ve/veya düzeltilmiş özgün metinler." (AOBM, 2015: 107).

\section{Özel Metinler}

“Örneğin, özgün metinlere benzeyecek şekilde hazırlanmış metinler (özellikle sanatçlar tarafından seslendirilen ve özel olarak dinleme-anlama için hazırlanmış metinler) Öğretilecek olan dilbilimsel içeriğin belli bağlamlarda geçen örneklerini vermek üzere hazırlanmış metinler (belirli bir ders ünitesi içinde) Sesbilim ve dilbilgisini yorumlayan, alıştırma amaçlı tek tek birbirinden bağımsız cümleler, Ders düzey yönergeleri, açıklamaları vs., test ve sınav açıklamaları, öğretmenin sınıfta kullandığı sınıf dili (açıklamalar, sınıf yönetimi, yönlendirmeler). Bunlar özel metin türleri sayılabilir. Kullanımları kolay mıdır? Kolay kullanımı sağlamak için, içerik ve oluşum ile malzemenin sunumu bakımından nelere dikkat etmek gerekir?" (AOBM, 2015: 107).

Görüldüğü gibi, AOBM'de hedef kitlenin düzeyine uygun hale getirmek amaciyla sadeleştirilmiş ve düzeltilmiş metinler de özgün metin olarak ele alınmıştır. Çalışmada metinlerin özgünlük/özellik durumlarının incelenmesi sırasında $\mathrm{AOBM}^{\prime}$ den alınan kriterler göz önünde bulundurulmuştur. $\mathrm{Bu}$ bağlamda, metinler özgün ve özel olarak sınıflandırılmış, ayrıca özgün metinler de kendi içerisinde özgün metin ve düzeltilmiş özgün metin olarak ayrılmıştır.

“İstanbul Yabancilar İçin Türkçe Seti"nde yer alan okuma metinlerindeki kültürel unsurlar incelenirken ise Saraç ve Arıkan (2010) tarafından geliştirilen "Yabancı Dil Ders Kitaplarında Hedef Kültür Bilgisini İncelemede Kullanılabilecek Kontrol Listesi” kullanılmıştır. Çalışmada kullanılan kontrol listesi "bakış açısı" ve "unsurlar/ögeler" olmak üzere iki bölümden oluşmaktadır.

Birinci bölüm olan "bakış açısı" na yönelik bölüm; “Öğrenci kendi deneyiminden yola çıkarak hedef kültürü tanımlar, öğrenci kendi kültürünü de düşünür ve tartışır, hedef ve yerel kültür karşılaştırılır, hedef kültürde yer alan alt kültürlere yer verilmiştir, hedef kültürün evrensel kültüre yaptığı katkılar verilmiştir, hedef kültür diğer kültürlerden üstün olarak tanımlanmıştır, hedef kültürün baskın değer ve alışkanlıklarına aykırı düşen değer ve alışkanlıklar yer alır, hedef kültür eleştirel bir şekilde ele alınmıştır." maddelerinden oluşmaktadır.

İkinci bölüm "unsurlar/ögeler" ise "Hedef kültür-bilim ilişkisi yer almaktadır, hedef kültüre ait dini bilgiler yer almaktadır, hedef kültüre ait siyasi bilgiler yer almaktadır, hedef kültüre ait görsel ve plastik sanatsal bilgiler yer almaktadır, hedef kültürde gündelik yaşamlara ait bilgiler yer almaktadır, hedef kültüre ait edebiyat yer almaktadır, hedef kültüre ait musiki bilgileri yer almaktadır, hedef kültürün spor çalışmaları yer almaktadır, hedef kültüre hizmet etmiş insanlar yer almaktadır, hedef kültürün diğer kültürlerden edindiği bilgi ve alışkanlıklar yer alır, hedef kültüre ait filmler yer alır, hedef kültüre ait hastalık ve sağlık bilgileri yer alır, hedef kültüre ait beslenme alışkanlıkları yer alır, hedef kültüre ait temizlik alışkanlıkları yer alır, hedef kültüre ait giyinme ve süslenme alışkanlıkları yer alır. Hedef kültürde aile kurumuna ait bilgiler yer alır, hedef kültürde üreme ve cinsel sağlıkla 
ilgili bilgiler vardır, hedef kültürde eğlence hayatıyla ilgili bilgiler vardır, hedef kültür-çevre ilişkisi (hayvan, bitki, doğa-insan ilişkisi) yer alır, hedef kültürde gelenek, festival ve kutlamalarla ilgili bilgiler vardır, hedef kültüre ait tarihi eser ve bilgiler yer almaktadır, hedef kültüre ait coğrafi bilgiler yer almaktadır, hedef kültüre ait okul ve eğitim yaşantıları yer almaktadır." maddelerinden oluşmaktadır (Saraç ve Arıkan, 2010).

\section{Yöntem}

Bu nitel araştırmada, doküman analizi tekniğinden yararlanılmıştır. Yıldırım ve Şimşek (2018), doküman incelemesini, araştırılması amaçlanan alana yönelik bilgileri içeren yazılı kaynakların analizi olarak ifade etmektedir. Bu bağlamda, çalışmada doküman olarak "İstanbul Yabancılar İçin Türkçe Seti"nde yer alan ders kitapları ele alınmıştır. Serin ve Turan (2015) temel düzey olarak adlandırılan A1 ve A2 düzeylerine yönelik ders kitaplarındaki metinlerin, çok kısa olduğunu ve tür özelliklerini yeterince yansıtmadığını belirtmektedir. Bu bağlamda, araştırmada B1, B2 ve C1+ düzeyindeki ders kitapları üzerinde çalışılmıştır.

Veri toplama sürecine "İstanbul Yabancılar İçin Türkçe Seti"ndeki (B1, B2, C1+) okuma metinlerinin tespit edilmesi ile başlanmıştır. Tespit edilen metinler, türlerine göre sınıflandırılmıştır. Metinlerin özgünlük/özellik durumları belirlenmiş ve "özgün metin”, "özel metin" başlıkları altında kategorilere ayrılmıştır. Son aşamada ise Saraç ve Arıkan (2010) tarafından geliştirilen "Yabancı Dil Ders Kitaplarında Hedef Kültür Bilgisini İncelemede Kullanılabilecek Kontrol Listesi" bağlamında okuma metinlerinde yer alan kültürel ögelerin belirlenmesine çalışılmıştır. Araştırmada elde edilen veriler, içerik analizi yoluyla çözümlenmiş ve sayısal verilerden yararlanılarak tablolaştırılmıştır. Büyüköztürk (2015) özellikle sosyal bilimlerde yoğun olarak kullanılan içerik analizi tekniğini, metinlerde geçen sözcüklerin belli kodlamalarla kategorilere ayrılarak ifade edildiği sistematik ve yeniden oluşturulabilir bir teknik olarak tanımlamaktadır.

\subsection{Sinirlılıklar}

Araştırma, “İstanbul Yabancılar İçin Türkçe Seti” nin orta (B1, B2) ve ileri (C1+) düzeyleri ile sınırlıdır. Bu bağlamda çalışmanın; farklı setler ve farklı setlerde yer alan başlangıç, orta ve ileri düzeylerdeki (A1, A2, B1, B2, C1, C2) kitaplar da dâhil edilerek yapılmasının derinlemesine genellemelere ulaşılmasına imkân sağlayacağı varsayılmaktadır.

Çalışma "İstanbul Yabancılar İçin Türkçe Seti"nde yer alan B1, B2 ve C1+ kitapları ile sınırlıdır. Bu bağlamda araştırmanın, temel düzeyindeki A1 ve A2 kitaplarının da dâhil edilerek yapılması çalışma sonuçlarının genellenmesine katkı sağlayacaktır.

\subsection{Alt Problemler}

Bu çalışmada, "İstanbul Yabancılar İçin Türkçe Seti"nde (B1, B2, C1+) yer alan okuma metinlerinin türlerini, metinlerin özgünlük/özellik durumlarını ve kültürel ögeleri içerme düzeylerini belirlemek amacıyla aşağıdaki sorulara cevap aranmıştır:

“İstanbul Yabancılar İçin Türkçe Seti”nde (B1, B2, C1+) yer alan okuma metinlerinin;

1. İsimlendirilmelerine göre dağılımı nedir?

2. Türleri ve türlerinin düzeylere göre dağılımı nedir?

3. Özgünlük/özellik durumları ve özgünlük/özellik durumlarının düzeylere göre dağılımı nedir?

4. Kültürel ögeleri içerme düzeyleri nedir? 
Şekil 2. Araştırmaya Yönelik Alt Problemler

Yabancilara Türkçe

Öğretimi İstanbul

Seti'nde (B1, B2, C1+)

yer alan okuma

metinlerinin;
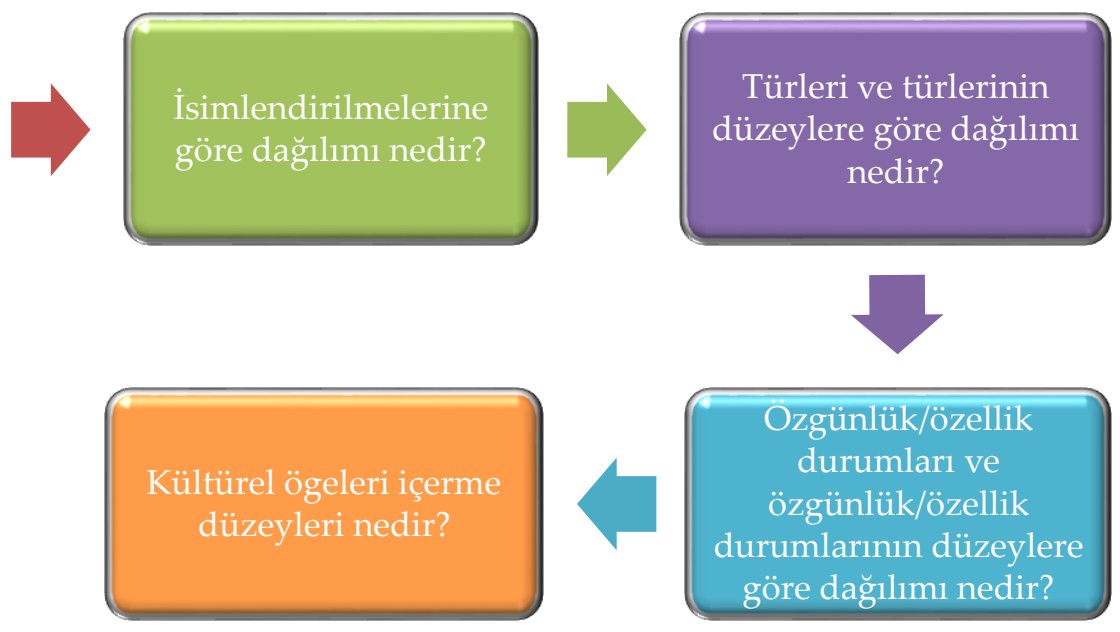

Özgünlük/özellik

durumları ve

özgünlük/özellik

durumlarının düzeylere

göre dağılımı nedir?

\section{Bulgular}

Bu bölümde, "İstanbul Yabancilar İçin Türkçe Seti"nde (B1, B2, C1+) yer alan okuma metinlerinden elde edilen bulgulara yer verilmiştir.

Bulgular, araştırmanın alt problemlerine yönelik; "İstanbul Yabancılar İçin Türkçe Seti” nde (B1, B2, $\mathrm{C} 1+)$ yer alan okuma metinlerinin isimlendirilmelerine, okuma metinlerinin türleri ve türlerinin düzeylere göre dağılımına, metinlerin özgünlük/özellik durumları ve özgünlük/özellik durumlarının düzeylere göre dağılımına ve kültürel ögeleri içerme düzeyine yönelik bulgular başlıkları altında sunulmuştur. Okuma metinlerinin kültürel ögeleri içerme düzeyinin belirlenmesinde, Saraç ve Arıkan (2010) tarafından geliştirilen "Yabancı Dil Ders Kitaplarında Hedef Kültür Bilgisini İncelemede Kullanılabilecek Kontrol Listesi"nde yer alan maddelerden yararlanılmıştır. İlgili maddelere yönelik bulgular tablolalaştırılarak sunulmuştur (Tablo 4, Tablo 5, Tablo 6, Tablo 7, Tablo 8, Tablo 9).

İstanbul Yabancılar İçin Türkçe Seti"nde (B1, B2, C1+) yer alan okuma metinlerinin kültürel ögeleri içerme düzeylerine yönelik bulgular "Yabancı Dil Ders Kitaplarında Hedef Kültür Bilgisini İncelemede Kullanılabilecek Kontrol Listesi"nde yer alan alt boyutları kapsayacak şekilde sunulmuştur. Bulguların sunumu esnasında, muhtemel belirsizliği önlemek amacıyla, "Yabancı Dil Ders Kitaplarında Hedef Kültür Bilgisini İncelemede Kullanılabilecek Kontrol Listesi"nde yer alan üç boyut ('hiç', 'nadiren', 'çoklukla'), araştırmacılar tarafından sırasıyla 'birinci alt boyut', 'ikinci alt boyut' ve 'üçüncü alt boyut' olarak ifade edilmiştir. 


\section{1. "İstanbul Yabancılar İçin Türkçe Seti"nde (B1, B2, C1+) yer alan okuma metinlerinin isimlendirilmelerine yönelik bulgular}

Tablo 2'de "İstanbul Yabancılar İçin Türkçe Seti"nde (B1, B2, C1+) yer alan okuma metinlerinin isimlerine, adedine ve sayfa numaralarına yönelik bulgulara yer verilmiştir.

Tablo 2. "İstanbul Yabancilar İçin Türkçe Seti”nde (B1, B2, C1+) Yer Alan Okuma Metinlerinin İsimlendirilmelerine Yönelik Bulgular

\begin{tabular}{|c|c|c|c|c|c|}
\hline \multicolumn{3}{|c|}{ B1 } & \multicolumn{3}{|c|}{ B2 } \\
\hline $\begin{array}{l}\text { Metin } \\
\text { No }\end{array}$ & Metin Adı & $\begin{array}{l}\text { Sayfa } \\
\text { No }\end{array}$ & $\begin{array}{l}\text { Metin } \\
\text { No }\end{array}$ & Metin Adı & $\begin{array}{c}\text { Sayfa } \\
\text { No }\end{array}$ \\
\hline 1 & Nasıl Bir Ev Arıyorsunuz? & 9 & 1 & Bavul Hazırlama Sanatı & 8 \\
\hline 2 & Nereye Gideceğiz? & 12 & 2 & Turizmde Çek-Yat Yöntemi & 13 \\
\hline 3 & İçimdeki Türkiye'm & 16 & 3 & Meryem Ana Evi & 16 \\
\hline 4 & İş Hayatındaki Roller & 25 & 4 & Çocukluğumdan Bugüne Teknoloji & 25 \\
\hline 5 & Yoğurdun Steve Jobs'u & 29 & 5 & Günümüzde İletişim & 30 \\
\hline 6 & Meslek Seçimi & 32 & 6 & Ulaşım Araçları & 34 \\
\hline 7 & Sağlığın Anahtarı & 40 & 7 & Kişilik ve Karakter & 45 \\
\hline 8 & Yüz Yaşında Hala Dinç & 43 & 8 & Renklerin İnsan Psikolojisine Etkisi & 48 \\
\hline 9 & Kristal Tedavileri & 48 & 9 & Duygusal Zekâ & 53 \\
\hline 10 & $\begin{array}{c}\text { Herkes Aynı Şekilde Mi } \\
\text { Öğrenir? }\end{array}$ & $56-57$ & 10 & Moda Nedir, Ne Değildir? & 60 \\
\hline 11 & Türkçe Farklı Bir Dil & 60 & 11 & Kalıcı Moda Var Mıdır? & 63 \\
\hline 12 & Vazgeçmek İçin Çok Erken & 63 & 12 & Dikkat! Giysileriniz Konuşuyor! & 67 \\
\hline 13 & "Keşke" Oynayalım Mı? & 70 & 13 & Peri Bacaları & 74 \\
\hline 14 & $\begin{array}{l}\text { Pişmanlıklarınızdan } \\
\text { Kurtulun }\end{array}$ & 74 & 14 & Tac Mahal & 78 \\
\hline 15 & Murphy Kanunları & 79 & 15 & İlginç İcatlar & 82 \\
\hline 16 & Öğrenci Evi & 87 & 16 & $\begin{array}{c}\text { İnsan Vücuduyla İlgili } \\
\text { Bilmediklerimiz }\end{array}$ & 91 \\
\hline 17 & Türk Aile Yapısı & $90-91$ & 17 & Başarabilmek & 96 \\
\hline 18 & Komşuluk Ölüyor & 94 & 18 & Bunları Biliyor Musunuz? & 101 \\
\hline
\end{tabular}


Tablo 2'nin devamı...

\begin{tabular}{|c|c|c|c|c|c|}
\hline \multicolumn{3}{|c|}{$\mathrm{C1+}$} & \multicolumn{3}{|c|}{ C1+ } \\
\hline $\begin{array}{l}\text { Metin } \\
\text { No }\end{array}$ & Metin Adı & $\begin{array}{c}\text { Sayfa } \\
\text { No }\end{array}$ & $\begin{array}{l}\text { Metin } \\
\text { No }\end{array}$ & Metin Adı & Sayfa No \\
\hline 1 & Saatin İcadı & $10-11$ & 19 & Sanat Nedir? & 116 \\
\hline 2 & 24 Saat Yetmiyorsa & $16-17$ & 20 & Sanat Türleri & $120-121$ \\
\hline 3 & $\begin{array}{l}\text { Ünlü Bilim Adamlarının } \\
\text { Çocuklukları }\end{array}$ & $21-22$ & 21 & Türk Süsleme Sanatları & 123 \\
\hline 4 & Aşkın Kimyası & $32-33$ & 22 & Suç Nedir? & $130-131$ \\
\hline 5 & $\begin{array}{c}\text { Ünlü Aşıklar ve Aşk } \\
\text { Mektupları }\end{array}$ & 38 & 23 & Adalet Nedir? & 133 \\
\hline 6 & Aşkın Sırrı & $41-42$ & 24 & Esaretin Bedeli & $136-137$ \\
\hline 7 & $\begin{array}{c}\text { Büyük İkramiyeyi Kazanıp } \\
\text { Sonra Kaybedenler }\end{array}$ & $50-51$ & 25 & Mizah Her Kapıyı Açar & $144-145$ \\
\hline 8 & Satranç ve Tavla & $55-56$ & 26 & Mizah Türleri & $148-149$ \\
\hline 9 & Elmas Gerdanlık & $58-59$ & 27 & Hasan Kaçan & 152 \\
\hline 10 & Arzuhalden Dilekçeye & 66 & 28 & Dünden Bugüne Para & 161 \\
\hline 11 & $\begin{array}{c}\text { İş Görüşmelerinde İşverenler } \\
\text { Nelere Dikkat Eder? }\end{array}$ & 69 & 29 & $\begin{array}{c}\text { Türkiye'de Enflasyonun Tarihsel } \\
\text { Gelişimi }\end{array}$ & 166 \\
\hline 12 & $\begin{array}{c}\text { Fatih Sultan Mehmet } \\
\text { Mahkemede } \\
\end{array}$ & 72 & 30 & $\begin{array}{c}\text { Öğrenciler İçin Tasarruf } \\
\text { Yöntemleri } \\
\end{array}$ & 170 \\
\hline 13 & Lumiere Kardeşler & 80 & 31 & Dünyamız & 178 \\
\hline 14 & Susuz Yaz & $85-86$ & 32 & Küresel Isınma Nedir? & 181 \\
\hline 15 & $\begin{array}{c}\text { Yabancı Ülkelerde Yayınlanan } \\
\text { Türk Dizileri } \\
\end{array}$ & $90-91$ & 33 & Dünya'dan Mars'a & 185 \\
\hline 16 & Bilge ve Bilgelik & $\begin{array}{c}100- \\
101 \\
\end{array}$ & 34 & Gençlerin Medya Tüketimi & 192 \\
\hline 17 & Bilgi Teknolojisi & 104 & 35 & Mert'in İletişim Serüveni & 197 \\
\hline 18 & Bilgi Toplumu ve Üniversiteler & 108 & 36 & İnternet ve Medya Bağımlılı̆̆ & 202 \\
\hline
\end{tabular}

Tablo 2'de; B1, B2, C1+ kitaplarında yer alan okuma metinlerinin isimlerine, adedine ve bulundukları sayfa numaralarına yer verilmiştir. Elde edilen bulgulara göre, B1 ve B2 düzeylerinde 18'er metin, C1+ düzeyinde ise 36 metnin yer aldığı görülmektedir. Tüm sette toplamda 72 okuma metni yer almaktadır. C1+ düzeyinin diğer düzeylere göre daha fazla metin içermesinin, C1+ düzeyi ve C2 düzeyine yönelik içerikleri de kapsamasından kaynaklandığı düşünülmektedir. B1 düzeyinde yer alan metinler: “Nasıl Bir Ev Arıyorsunuz?, Nereye Gideceğiz?, İçimdeki Türkiyem, İş Hayatındaki Roller, Yoğurdun Steve Jobs'u, Meslek Seçimi vb." şeklindedir.

B2 düzeyinde yer alan metinler: “Bavul Hazırlama Sanatı, Turizmde Çek-Yat Yöntemi, Meryem Ana Evi, Çocukluğumdan Bugüne Teknoloji, Günümüzde İletişim, Ulaşım Araçları vb.” şeklindedir.

C1+ düzeyinde yer alan metinler ise "Saatin İcadı, 24 Saat Yetmiyorsa, Ünlü Bilim Adamlarının Çocuklukları, Aşkın Kimyası, Ünlü Âşıklar ve Aşk Mektupları, Aşkın Sırrı, Büyük İkramiyeyi Kazanıp Sonra Kaybedenler, Satranç ve Tavla, Elmas Gerdanlık, Arzuhalden Dilekçeye, İş Görüşmelerinde İşverenler Nelere Dikkat Eder?, Fatih Sultan Mehmet Mahkemede vb." şeklindedir. 


\section{2. "İstanbul Yabancılar İçin Türkçe Seti"nde (B1, B2, C1+) yer alan okuma metinlerinin türleri ve türlerinin düzeylere göre dağılımına yönelik bulgular}

Grafik 1. B1, B2, C1+ Düzeylerindeki Metinlerin Türlerine Göre Dağılımı

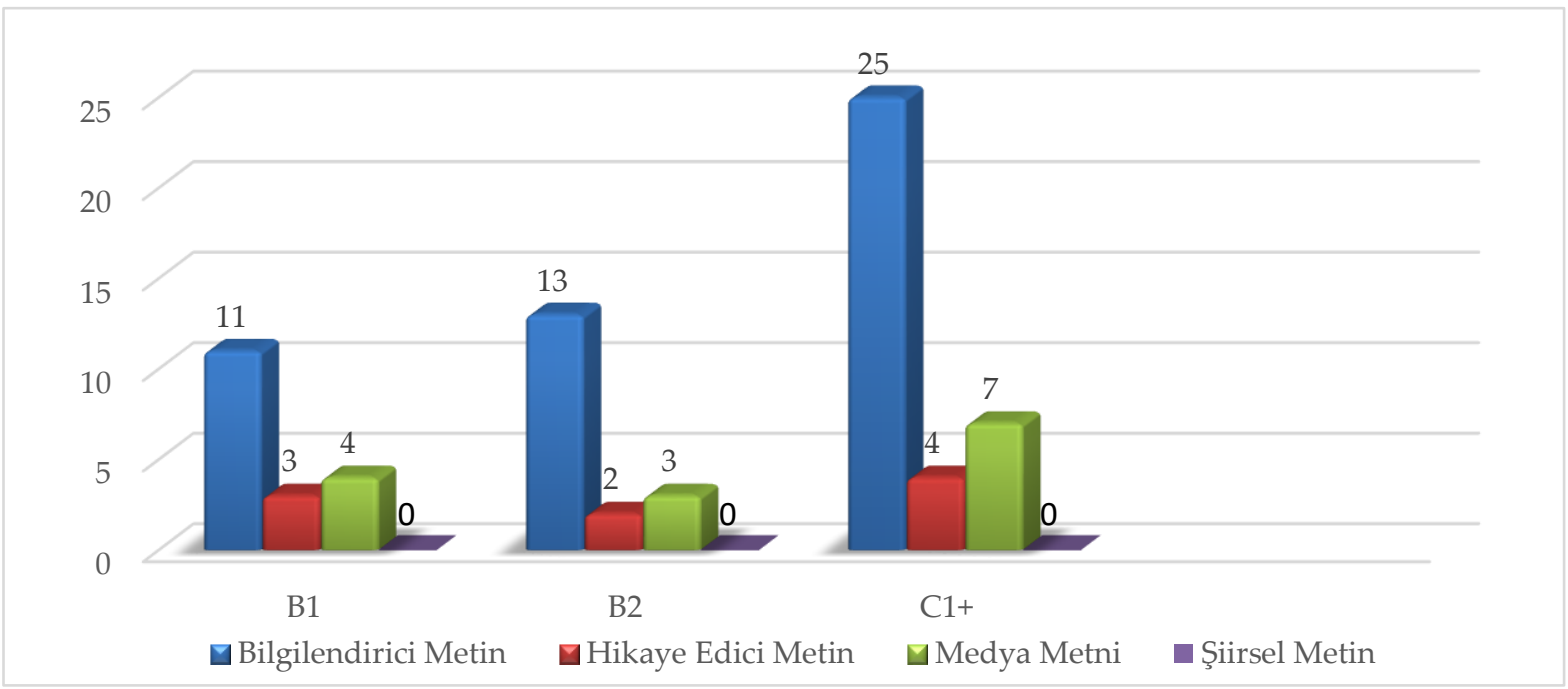

Grafik 1'de görüldüğü gibi, B1, B2, C1+ düzeylerindeki okuma metinleri; bilgilendirici metinler, hikâye edici metinler ve medya metinleri olmak üzere üç grup altında dağılım göstermiştir. B1 düzeyinde 11, B2 düzeyinde 13, C1+ düzeyinde ise 25 adet bilgilendirici metin tespit edilmiştir. B1 düzeyinde 3, B2 düzeyinde 2, C1+ düzeyinde 4 adet hikâye edici metin yer almaktadır. B1 düzeyinde 4, B2 düzeyinde 3, C1+ düzeyinde ise 7 adet medya metnine yer verilmiştir. B1, B2, C1+ düzeylerinde toplam 49 bilgilendirici metin, 9 hikâye edici metin, 14 medya metni tespit edilmiştir. B1, B2, C1+ düzeylerinde en çok bilgilendirici metin, en az ise hikâye edici metinler bulunmaktadır. Metinler türlerine göre incelendiğinde, şiirsel metinlere yer verilmediği görülmektedir.

Grafik 2. B1, B2, C1+ Düzeylerindeki Bilgilendirici Metinlerin Türlerine Göre Dağılımı

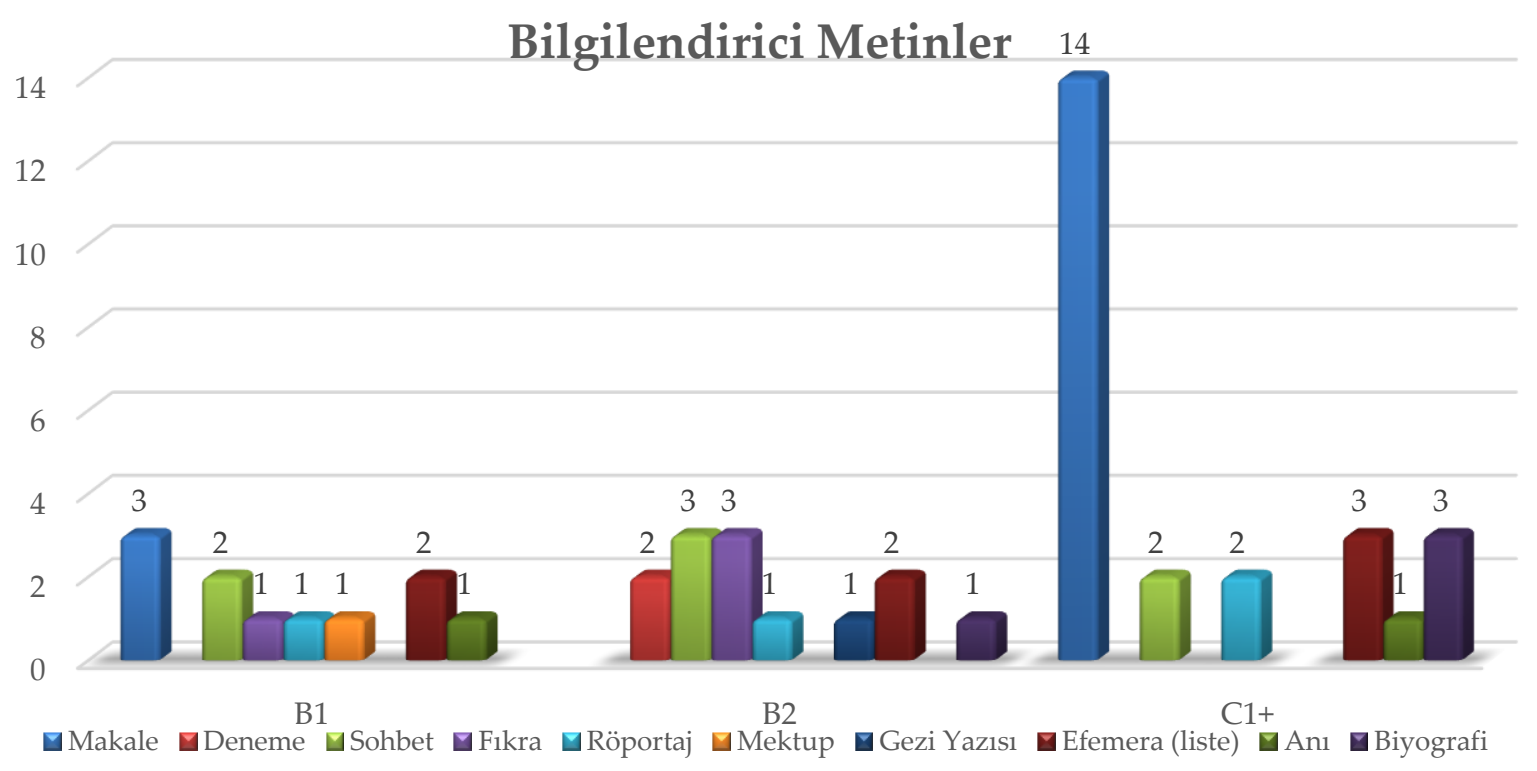


Grafik 2 incelendiğinde, B1, B2, C1+ düzeylerinde bilgilendirici metinlerden; makale (17), deneme (2), fıkra (4), sohbet (7), röportaj (4), mektup (1), gezi yazısı (1), efemera (liste) (7), anı (2), biyografi (4) türlerinin yer aldığı görülmektedir. İncelenen ders kitaplarında, 49 adet bilgilendirici metin tespit edilmiştir.

B1 düzeyindeki okuma metinlerinde, bilgilendirici metinlerden makale (3), sohbet (2), efemera (liste) (2), röportaj (1), fıkra (1), mektup (1), anı (1) türlerine yer verilmiştir. B1 düzeyinde deneme, gezi yazısı, biyografi türlerine rastlanmamıştır. B1 düzeyinde toplamda 11 adet bilgilendirici metin tespit edilmiştir. B2 düzeyindeki okuma metinlerinde bilgilendirici metinlerden; sohbet (3), fikra (3), deneme (2), efemera (liste) (2), röportaj (1), gezi yazısı (1), biyografi (1) türleri yer almaktadır. B2 düzeyindeki okuma metinlerinde, toplamda 13 adet bilgilendirici metin tespit edilmiştir. B2 düzeyindeki okuma metinlerinde, makale, mektup ve anı türüne yer verilmemiştir. C1+ düzeyindeki okuma metinlerinde, bilgilendirici metinlerden; makale (14), efemera (liste) (3), biyografi (3), sohbet (2), röportaj (2), anı (1) türlerine yer verilmiştir. C1+ düzeyinde toplamda 25 adet bilgilendirici metin tespit edilmiştir. $\mathrm{C} 1+$ düzeyinde deneme, fıkra, mektup ve gezi yazısı türlerine rastlanmamıştır. İncelenen B1, B2, C1+ düzeylerindeki okuma metinlerinde en çok makale türü, en az gezi yazısı ve mektup türü bulunmaktadır.

Grafik 3. B1, B2, C1+ Düzeylerindeki Hikâye Edici Metinlerin Türleri ve Metinlerin Türlerine Göre Dağılımı

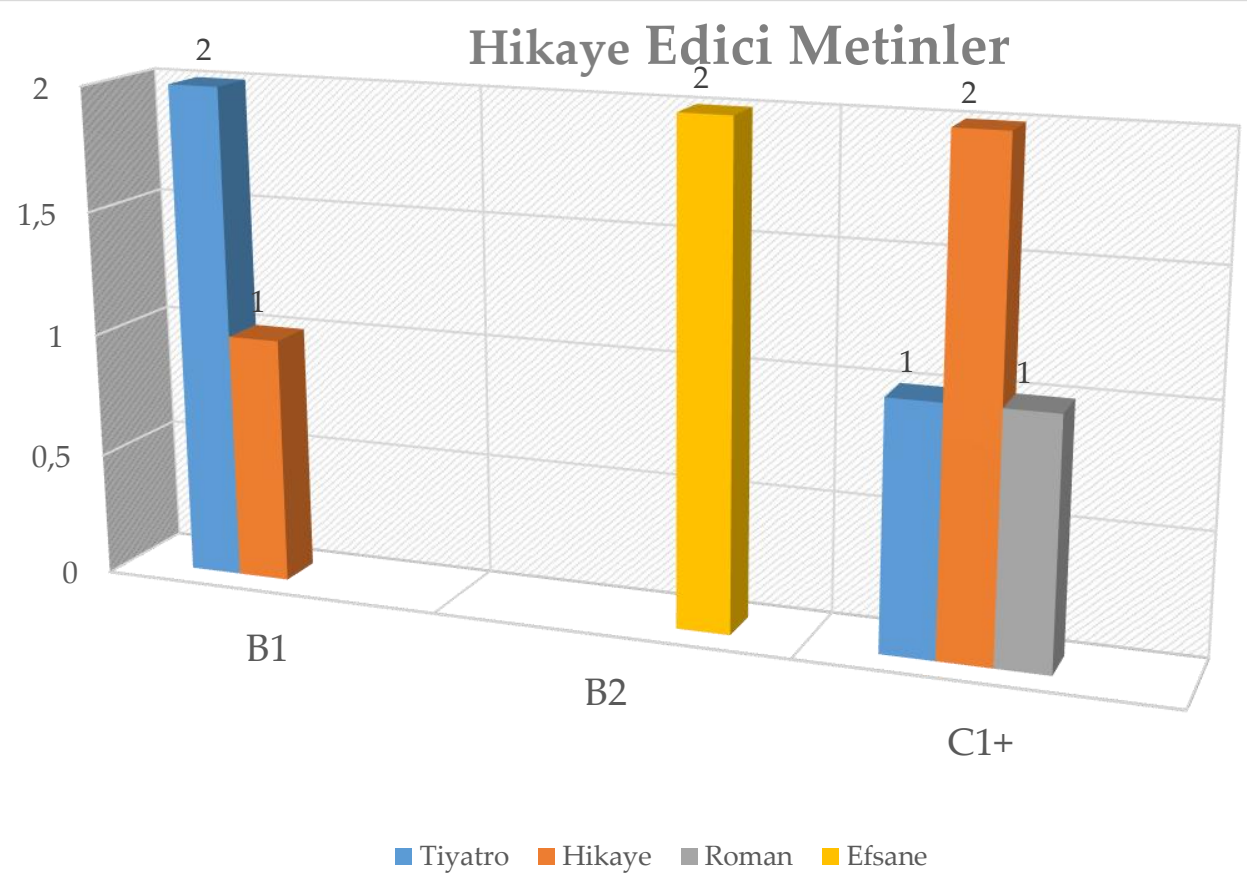

Grafik 3 incelendiğinde, B1, B2, C1+ düzeylerinde hikâye edici metinlerin türleri; tiyatro, hikâye, roman ve efsane olarak tespit edilmiştir. B1 düzeyinde, tiyatro (2), hikâye (1); B2 düzeyinde efsane (2); C1+ düzeyinde ise tiyatro (1), hikâye (2) ve roman (1) türleri yer almaktadır. B1, B2, C1+ düzeylerindeki okuma metinlerinde hikâye edici metinlerin, bilgilendirici metinlere göre daha az yer aldığ1 görülmektedir. İncelenen B1, B2, C1+ düzeylerindeki okuma metinlerinde, hikâye edici metinlerden en çok tiyatro (3), en az roman (1) türü bulunmaktadır. 
Grafik 4. B1, B2, C1+ Düzeylerindeki Medya Metinlerinin Türleri ve Metinlerin Türlerine Göre Dağılımı

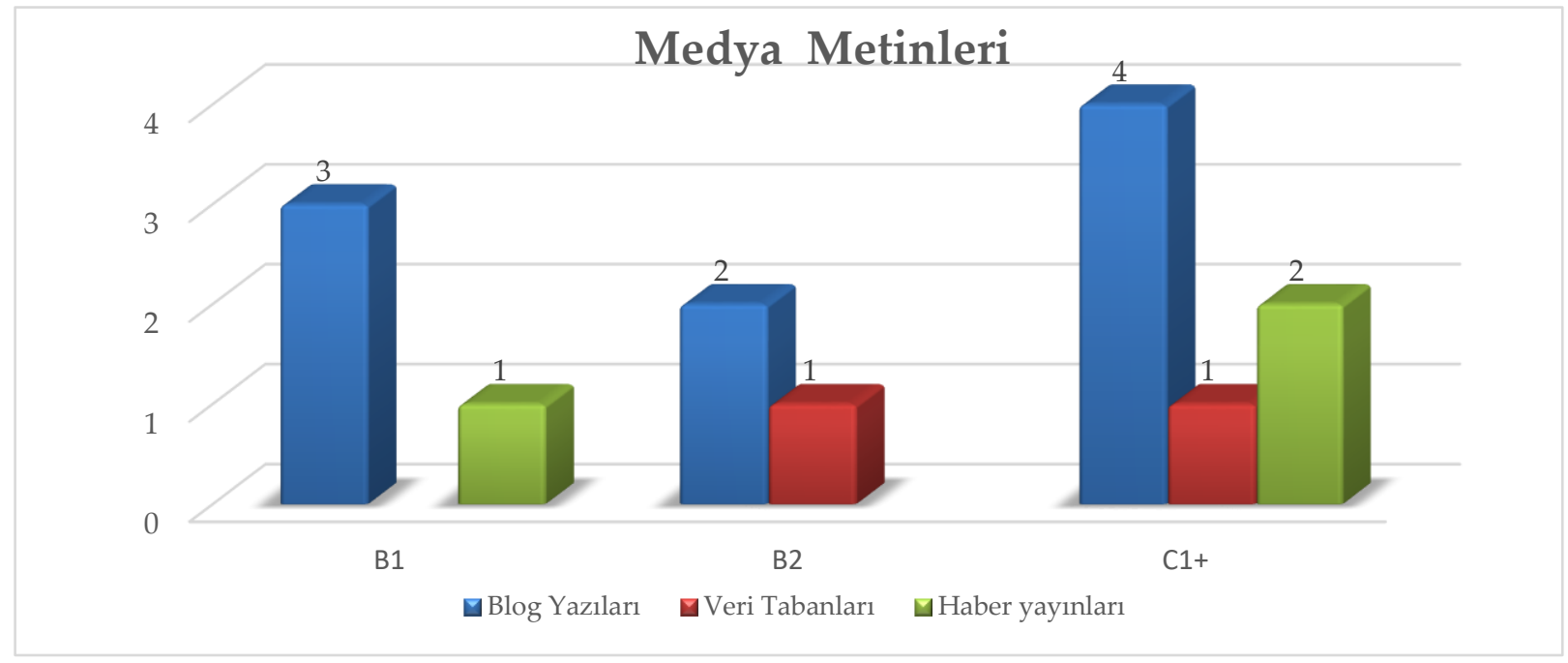

Grafik 4 incelendiğinde, B1, B2, C1+ düzeylerinde, medya metinlerinden blog yazıları, veri tabanları ve haber yayınları türleri yer aldığı görülmektedir. B1 düzeyinde, blog yazısı (3), haber yayını (1); B2 düzeyinde, blog yazısı (2), veri tabanı (1); C1+ düzeyinde, blog yazısı (4), haber yayını (2), veri tabanı (1) türlerine yer verilmiştir. B1, B2, C1+ düzeylerinde en çok blog yazısı (9), en az roman (1) türünün yer aldığı belirlenmiştir.

\section{3. “İstanbul Yabancılar İçin Türkçe Seti”nde (B1, B2, C1+) yer alan okuma metinlerinin özgünlük/özellik durumları ve özgünlük/özellik durumlarının düzeylere göre dağılımına yönelik bulgular}

Grafik 5. Okuma Metinlerindeki Özgünlük/Özellik Durumu

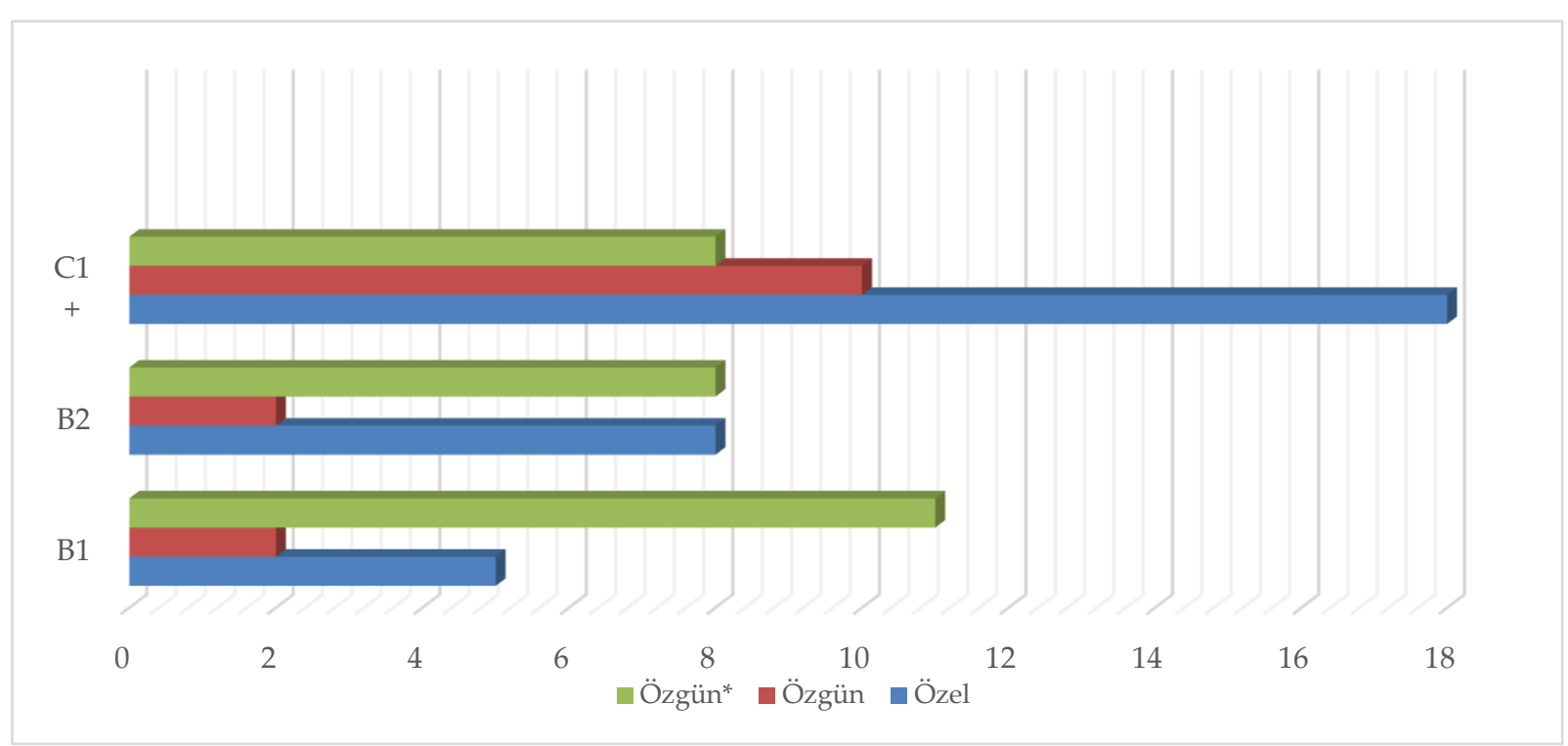

Okuma metinlerinin, özgünlük/özellik durumlarına ve özgünlük/özellik durumlarının düzeylere dağ1lımına yönelik Grafik 5'te yer alan bulgulara göre; B1 düzeyinde (5), B2 düzeyinde (8), C1+ düzeyinde ise (18) adet özel metin tespit edilmiştir. Diğer taraftan, B1 düzeyinde (2), B2 düzeyinde (2), 
C1+ düzeyinde ise (10) adet özgün metnin yer aldığ1 görülmüştür. Özgün* metinlerin ise B1 düzeyinde (11), B2 düzeyinde (8), C1+ düzeyinde (8) adet olduğu görülmektedir.

Tablo 3. Okuma Metinlerindeki Özgünlük/Özellik Durumu

\begin{tabular}{cccc}
\hline Kitaplar & Özel & Özgün & Özgün \\
\hline B1 & 5 & 2 & 11 \\
B2 & 8 & 2 & 8 \\
C1+ & 18 & 10 & 8 \\
Toplam (f) & 31 & 14 & 27 \\
\hline
\end{tabular}

Tablo 3'teki bulgular göz önüne alındığında, B1, B2, C1+ düzeylerinde 31 özel metin, 14 özgün metin, 27 adet özgün* metin tespit edilmiştir.

3.4. "İstanbul Yabancılar İçin Türkçe Seti"nde (B1, B2, C1+) yer alan okuma metinlerinin kültürrel ögeleri içerme düzeyine yönelik bulgular

Tablo 4. Okuma Metinlerinin Kültürel Ögeleri İçerme Düzeyi “Bakış Açısı” (Çoklukla)

\begin{tabular}{lcccc}
\hline \multicolumn{1}{|c}{ Bakış Açısı (Çoklukla) } & $\begin{array}{c}\text { B1 } \\
\text { (f) }\end{array}$ & $\begin{array}{c}\text { B2 } \\
\text { (f) }\end{array}$ & $\begin{array}{c}\text { C1+ } \\
\text { (f) }\end{array}$ & $\begin{array}{c}\text { Toplam } \\
\text { (f) }\end{array}$ \\
\hline Öğrenci kendi deneyiminden yola çıkarak hedef kültürü tanımlar. & 3 & 0 & 0 & 3 \\
\hline Öğrenci kendi kültürünü de düşünür tartışır. & 5 & 1 & 2 & 8 \\
\hline Hedef ve yerel kültür karşılaştırılır. & 3 & 0 & 1 & 4 \\
\hline Hedef kültürde yer alan alt külttürlere yer verilmiştir. & 4 & 0 & 2 & 6 \\
\hline Hedef kültürün evrensel kültüre yaptığı katkılar verilmiştir. & 0 & 0 & 5 & 5 \\
\hline Hedef kültür diğer kültürlerden üstün olarak tanımlanmıştır. & 0 & 0 & 0 & 0 \\
\hline $\begin{array}{l}\text { Hedef kültürün baskın değer ve alışkanlıklarına aykırı düşen } \\
\text { değer ve alışkanlıklar yer alır. }\end{array}$ & 2 & 0 & 1 & 3 \\
\hline $\begin{array}{l}\text { Hedef kültür eleştirel bir şekilde ele alınmıştır. } \\
\text { Toplam (f) }\end{array}$ & 0 & 0 & 0 & 0 \\
\hline
\end{tabular}

Tablo 4'te "Yabancı Dil Ders Kitaplarında Hedef Kültür Bilgisini incelemede Kullanılabilecek Kontrol Listesi"nin kültürel ögeleri içerme düzeyine yönelik "Bakış Açısı" birinci alt boyutuna (çoklukla) ilişkin bulgular yer almaktadır.

Tablo 4'te görüldüğü üzere; B1, B2 ve C1+ düzeylerinde birinci alt boyut en çok “Öğrenci kendi kültürünü de düşünür tartışır." maddesinde tespit edilmişken, "Hedef kültür diğer kültürlerden üstün olarak tanımlanmıştır." ve "Hedef kültür eleştirel bir şekilde ele alınmıştır." maddelerinde birinci alt boyuta rastlanmamıştır.

Bu bağlamda, B1'de 17, B2'de 1, C1+ düzeyinde 11 kez olmak üzere birinci alt boyut toplamda 29 kez tespit edilmiştir.

* Özgün*(düzeltilmiș özgün metin) 
Tablo 5. Okuma Metinlerinin Kültürel Ögeleri İçerme Düzeyi “Bakış Açısı” (Nadiren)

\begin{tabular}{lcccc}
\hline Bakış Açısı (Nadiren) & $\begin{array}{c}\text { B1 } \\
\text { (f) }\end{array}$ & $\begin{array}{c}\text { B2 } \\
\text { (f) }\end{array}$ & $\begin{array}{c}\text { C1+ } \\
\text { (f) }\end{array}$ & $\begin{array}{c}\text { Toplam } \\
\text { (f) }\end{array}$ \\
\hline Öğrenci kendi deneyiminden yola çıkarak hedef kültürü tanımlar. & 7 & 10 & 8 & 25 \\
Öğrenci kendi kültürünü de düşünür tartışır. & 8 & 11 & 21 & 40 \\
Hedef ve yerel kültür karşılaştırılır. & 7 & 4 & 14 & 25 \\
Hedef kültürde yer alan alt kültürlere yer verilmiştir. & 7 & 3 & 8 & 18 \\
Hedef kültürün evrensel kültüre yaptığı katkılar verilmiştir. & 4 & 7 & 1 & 12 \\
Hedef kültür diğer kültürlerden üstün olarak tanımlanmıştır. & 2 & 0 & 2 & 4 \\
\hline $\begin{array}{l}\text { Hedef kültürün baskın değer ve alışkanlıklarına aykırı düşen değer ve } \\
\text { alışkanlıklar yer alır. }\end{array}$ & 4 & 1 & 1 & 6 \\
\hline Hedef kültür eleştirel bir şekilde ele alınmıştır. & 3 & 0 & 1 & 4 \\
\hline Toplam (f) & $\mathbf{4 2}$ & $\mathbf{3 6}$ & $\mathbf{5 6}$ & $\mathbf{1 3 4}$ \\
\hline
\end{tabular}

Tablo 5'te "Yabancı Dil Ders Kitaplarında Hedef Kültür Bilgisini incelemede Kullanılabilecek Kontrol Listesi" nin kültürel ögeleri içerme düzeyine yönelik "Bakış Açısı" ikinci alt boyutuna (nadiren) ilişkin bulgular yer almaktadir.

Tablo 5'te görüldüğü gibi; B1, B2 ve C1+ düzeylerinde ikinci alt boyuta en çok "Öğrenci kendi kültürünü de düşünür tartışır." maddesinde, en az "Hedef kültür eleştirel bir şekilde ele alınmıştır." ve "Hedef kültür diğer kültürlerden üstün olarak tanımlanmıştır." maddelerinde rastlanmıştır.

Bu bağlamda, B1'de 42, B2'de 36, C1+ düzeyinde 56 kez olmak üzere ikinci alt boyut toplamda 134 kez tespit edilmiştir.

Tablo 6. Okuma Metinlerinin Kültürel Ögeleri İçerme Düzeyi “Bakış Açısı” (Hiç)

\begin{tabular}{lcccc}
\hline Bakış Açısı (Hiç) & $\begin{array}{c}\text { B1 } \\
\text { (f) }\end{array}$ & $\begin{array}{c}\text { B2 } \\
\text { (f) }\end{array}$ & $\begin{array}{c}\text { C1+ } \\
\text { (f) }\end{array}$ & $\begin{array}{c}\text { Toplam } \\
\text { (f) }\end{array}$ \\
\hline Öğrenci kendi deneyiminden yola çıkarak hedef kültürü tanımlar. & 8 & 8 & 24 & 40 \\
Öğrenci kendi kültürünü de düşünür tartışır. & 5 & 6 & 13 & 24 \\
\hline Hedef ve yerel kültür karşılaştırılır. & 7 & 4 & 14 & 25 \\
\hline Hedef kültürde yer alan alt kültürlere yer verilmiştir. & 7 & 14 & 25 & 46 \\
\hline Hedef kültürün evrensel kültüre yaptığı katkılar verilmiştir. & 13 & 10 & 30 & 53 \\
Hedef kültür diğer kültürlerden üstün olarak tanımlanmıştır. & 15 & 18 & 34 & 67 \\
\hline $\begin{array}{l}\text { Hedef kültürün baskın değer ve alışkanlıklarına aykırı düşen değer ve } \\
\text { alışkanlıklar yer alır. }\end{array}$ & 11 & 17 & 33 & 61 \\
\hline Hedef kültür eleştirel bir şekilde ele alınmıştır. & 14 & 18 & 35 & 67 \\
\hline Toplam (f) & $\mathbf{8 0}$ & $\mathbf{9 5}$ & $\mathbf{2 0 8}$ & $\mathbf{3 8 3}$ \\
\hline
\end{tabular}

Tablo 6' da "Yabancı Dil Ders Kitaplarında Hedef Kültür Bilgisini incelemede Kullanılabilecek Kontrol Listesi" nin kültürel ögeleri içerme düzeyine yönelik "Bakış Açısı" üçüncü alt boyutuna (hiç) ilişkin bulgulara yer verilmiştir.

Tablo 6' da görüldüğü üzere; B1, B2 ve C1+ düzeylerinde üçüncü alt boyut en çok "Hedef kültür diğer kültürlerden üstün olarak tanımlanmıştır." ve "Hedef kültür eleştirel bir şekilde ele alınmıştır." 
maddelerinde belirlenmişken, en az "Öğrenci kendi kültürünü de düşünür tartışır." ve " Hedef ve yerel kültür karşılaştırılır." maddelerinde tespit edilmiştir.

Bu bağlamda, B1'de 80, B2'de 95, C1+ düzeyinde 208 kez olmak üzere üçüncü alt boyut toplamda 383 kez tespit edilmiştir.

Tablo 7. Okuma Metinlerinin Kültürel Ögeleri İçerme Düzeyi (Çoklukla)

\begin{tabular}{llccc}
\hline Kültürel Unsurlar -Ögeler (Çoklukla) & $\begin{array}{c}\text { B1 } \\
\text { (f) }\end{array}$ & $\begin{array}{c}\text { B2 } \\
\text { (f) }\end{array}$ & $\begin{array}{c}\text { C1+ } \\
\text { (f) }\end{array}$ & $\begin{array}{c}\text { Toplam } \\
\text { (f) }\end{array}$ \\
\hline Hedef kültür-bilim ilişkisi yer almaktadır. & 3 & 0 & 1 & 4 \\
\hline Hedef kültüre ait dini bilgiler yer almaktadır. & 0 & 0 & 0 & 0 \\
\hline Hedef kültüre ait siyasi bilgiler yer almaktadır. & 0 & 0 & 0 & 0 \\
\hline Hedef kültüre ait görsel, plastik ve sanatsal bilgiler yer almaktadır. & 0 & 0 & 2 & 2 \\
\hline Hedef kültürde gündelik yaşamlara ait bilgiler yer almaktadır. & 9 & 1 & 8 & 18 \\
\hline Hedef kültüre ait edebiyat yer almaktadır. & 1 & 1 & 3 & 5 \\
\hline Hedef kültüre ait musiki bilgileri yer almaktadır. & 0 & 0 & 0 & 0 \\
\hline Hedef kültürün spor çalışmaları yer almaktadır. & 0 & 0 & 0 & 0 \\
\hline Hedef kültüre hizmet etmiş insanlar yer almaktadır. & 1 & 2 & 5 & 8 \\
\hline Hedef kültürün diğer kültürden edindiği bilgi ve alışkanlıklar yer alır. & 5 & 0 & 9 & 14 \\
\hline Hedef kültür çevre ilişkisi( hayvan, bitki, doğa, insan ) yer alır. & 2 & 0 & 6 & 8 \\
\hline Hedef kültüre ait filmler yer alır. & 0 & 0 & 3 & 3 \\
\hline Hedef külttüre ait hastalık ve sağlık bilgileri yer alır. & 1 & 0 & 0 & 1 \\
\hline Hedef kültüre ait beslenme alışkanlıkları yer alır. & 3 & 0 & 0 & 3 \\
\hline Hedef kültüre ait temizlik alışkanlıkları yer alır. & 1 & 0 & 0 & 1 \\
\hline Hedef kültüre ait giyinme ve süslenme alışkanlıkları yer alır. & 0 & 2 & 1 & 3 \\
\hline Hedef kültürde aile kurumuna ait bilgiler yer alır. & 2 & 1 & 3 & 6 \\
\hline Hedef kültürde üreme ve cinsel sağlıkla ilgili bilgiler yer alır. & 0 & 0 & 0 & 0 \\
\hline Hedef kültürde eğlence hayatıyla ilgili bilgiler vardır. & 0 & 0 & 2 & 2 \\
\hline Hedef kültürde gelenek, festival ve kutlamalarla ilgili bilgiler yer alır. & 1 & 0 & 0 & 1 \\
\hline Hedef kültüre ait tarihi eser ve bilgiler yer almaktadır. & 0 & 2 & 2 & 4 \\
\hline Hedef kültüre ait coğrafi bilgiler yer almaktadır. & 0 & 0 & 2 & 2 \\
\hline Hedef kültüre ait okul ve eğitim yaşantıları yer almaktadır. & 5 & 0 & 6 & 11 \\
\hline Toplam (f) & 34 & 9 & 53 & 96 \\
\hline
\end{tabular}

Tablo 7'de "Yabancı Dil Ders Kitaplarında Hedef Kültür Bilgisini incelemede Kullanılabilecek Kontrol Listesi"nin kültürel ögeleri içerme düzeyine yönelik "Kültürel Unsurlar-Ögeler" birinci alt boyutuna (çoklukla) ilişkin bulgular değerlendirilmiştir.

Tablo 7'de görüldüğü üzere; B1, B2 ve C1+ düzeylerinde birinci alt boyut en çok "Hedef kültürde gündelik yaşamlara ait bilgiler yer almaktadır." maddesinde tespit edilmişken, "Hedef kültüre ait dini bilgiler yer almaktadır.", "Hedef kültüre ait siyasi bilgiler yer almaktadır." , "Hedef kültüre ait musiki bilgileri yer almaktadır." , "Hedef kültürün spor çalışmaları yer almaktadır." , "Hedef kültürde üreme ve cinsel sağlıkla ilgili bilgiler yer alır." maddelerinde birinci alt boyuta rastlanmamıştır.

Bu bağlamda, B1'de 34, B2' de 9, C1+ düzeyinde 53 kez olmak üzere birinci alt boyut toplamda 96 kez tespit edilmiştir. 
Tablo 8. Okuma Metinlerinin Kültürel Ögeleri İçerme Düzeyi “Kültürel Unsurlar-Ögeler" (Nadiren)

\begin{tabular}{lcccc}
\hline Kültürel Unsurlar-Ögeler (Nadiren) & $\begin{array}{c}\text { B1 } \\
\text { (f) }\end{array}$ & $\begin{array}{c}\text { B2 } \\
\text { (f) }\end{array}$ & $\begin{array}{c}\text { C1+ } \\
\text { (f) }\end{array}$ & $\begin{array}{c}\text { Toplam } \\
\text { (f) }\end{array}$ \\
\hline Hedef kültürr-bilim ilişkisi yer almaktadır. & 4 & 9 & 19 & 32 \\
\hline Hedef kültüre ait dini bilgiler yer almaktadır. & 5 & 4 & 3 & 12 \\
\hline Hedef kültüre ait siyasi bilgiler yer almaktadır. & 0 & 1 & 15 & 16 \\
\hline Hedef kültüre ait görsel, plastik ve sanatsal bilgiler yer almaktadır. & 1 & 10 & 12 & 23 \\
\hline Hedef kültürde gündelik yaşamlara ait bilgiler yer almaktadır. & 6 & 7 & 13 & 26 \\
\hline Hedef kültüre ait edebiyat yer almaktadır. & 2 & 2 & 22 & 26 \\
\hline Hedef kültüre ait musiki bilgileri yer almaktadır. & 0 & 1 & 0 & 1 \\
\hline Hedef kültürün spor çalışmaları yer almaktadır. & 0 & 1 & 0 & 1 \\
\hline Hedef kültüre hizmet etmiş insanlar yer almaktadır. & 1 & 0 & 7 & 8 \\
\hline Hedef kültürün diğer kültürden edindiği bilgi ve alışkanlıklar yer alır. & 8 & 17 & 17 & 42 \\
\hline Hedef kültür çevre ilişkisi( hayvan, bitki, doğa, insan ) yer alır. & 4 & 15 & 18 & 37 \\
\hline Hedef kültüre ait filmler yer alır. & 0 & 0 & 2 & 2 \\
\hline Hedef kültüre ait hastalık ve sağlık bilgileri yer alır. & 1 & 1 & 2 & 4 \\
\hline Hedef kültüre ait beslenme alışkanlıkları yer alır. & 2 & 1 & 0 & 3 \\
\hline Hedef kültüre ait temizlik alışkanlıkları yer alır. & 0 & 1 & 0 & 1 \\
\hline Hedef kültüre ait giyinme ve süslenme alışkanlıkları yer alır. & 0 & 5 & 3 & 8 \\
\hline Hedef kültürrde aile kurumuna ait bilgiler yer alır. & 5 & 5 & 9 & 19 \\
\hline Hedef kültürde üreme ve cinsel sağlıkla ilgili bilgiler yer alır. & 1 & 1 & 0 & 2 \\
\hline Hedef kültürrde eğlence hayatıyla ilgili bilgiler vardır. & 2 & 3 & 5 & 10 \\
\hline Hedef kültürde gelenek, festival ve kutlamalarla ilgili bilgiler yer alır. & 1 & 3 & 3 & 7 \\
\hline Hedef kültüre ait tarihi eser ve bilgiler yer almaktadır. & 1 & 3 & 2 & 6 \\
\hline Hedef kültüre ait coğrafi bilgiler yer almaktadır. & 1 & 8 & 8 & 17 \\
\hline Hedef kültüre ait okul ve eğitim yaşantıları yer almaktadır. & 2 & 5 & 12 & 19 \\
\hline Toplam (f) & 47 & 103 & 172 & 322 \\
\hline
\end{tabular}

Tablo 8'de “Yabancı Dil Ders Kitaplarında Hedef Kültür Bilgisini incelemede Kullanılabilecek Kontrol Listesi"nin kültürel ögeleri içerme düzeyine yönelik "Kültürel Unsurlar-Ögeler" ikinci alt boyutuna (nadiren) ilişkin bulgulara yer verilmiştir.

Tablo 8'de görüldügü gibi; B1, B2 ve C1+ düzeylerinde ikinci alt boyut en çok "Hedef kültürün diğer kültürden edindiği bilgi ve alışkanlıklar yer alır." maddesinde tespit edilmişken, en az "Hedef kültüre ait musiki bilgileri yer almaktadır." , "Hedef kültürün spor çalışmaları yer almaktadır." , "Hedef kültüre ait temizlik alışkanlıkları yer alır." maddelerinde tespit edilmiştir.

Bu bağlamda, B1'de 47, B2'de 103, C1+ düzeyinde 172 kez olmak üzere ikinci alt boyut toplamda 322 kez tespit edilmiştir. 
Tablo 9. Okuma Metinlerinin Kültürel Ögeleri İçerme Düzeyi “Kültürel Unsurlar-Ögeler” (Hiç)

\begin{tabular}{llccc}
\hline Kültürel Unsurlar - Ögeler (Hiç) & $\begin{array}{c}\text { B1 } \\
\text { (f) }\end{array}$ & $\begin{array}{c}\text { B2 } \\
\text { (f) }\end{array}$ & $\begin{array}{c}\text { C1+ } \\
\text { (f) }\end{array}$ & $\begin{array}{c}\text { Toplam } \\
\text { (f) }\end{array}$ \\
\hline Hedef kültürr-bilim ilişkisi yer almaktadır. & 11 & 9 & 16 & 34 \\
\hline Hedef kültüre ait dini bilgiler yer almaktadır. & 13 & 14 & 33 & 60 \\
\hline Hedef kültüre ait siyasi bilgiler yer almaktadır. & 18 & 17 & 21 & 56 \\
\hline Hedef kültüre ait görsel, plastik ve sanatsal bilgiler yer almaktadır. & 17 & 7 & 22 & 46 \\
\hline Hedef kültürrde gündelik yaşamlara ait bilgiler yer almaktadır. & 3 & 10 & 15 & 28 \\
\hline Hedef kültüre ait edebiyat yer almaktadır. & 15 & 15 & 11 & 41 \\
\hline Hedef kültüre ait musiki bilgileri yer almaktadır. & 18 & 17 & 36 & 71 \\
\hline Hedef kültürün spor çalışmaları yer almaktadır. & 18 & 17 & 36 & 71 \\
\hline Hedef kültüre hizmet etmiş insanlar yer almaktadır. & 16 & 16 & 24 & 56 \\
\hline Hedef kültürün diğer kültürden edindiği bilgi ve alışkanlıklar yer alır. & 5 & 1 & 10 & 16 \\
\hline Hedef kültür çevre ilişkisi( hayvan, bitki, doğa, insan ) yer alır. & 12 & 3 & 13 & 28 \\
\hline Hedef kültüre ait filmler yer alır. & 18 & 18 & 31 & 67 \\
\hline Hedef kültüre ait hastalık ve sağlık bilgileri yer alır. & 16 & 17 & 34 & 67 \\
\hline Hedef kültüre ait beslenme alışkanlıkları yer alır. & 13 & 17 & 36 & 66 \\
\hline Hedef kültüre ait temizlik alışkanlıkları yer alır. & 17 & 17 & 36 & 70 \\
\hline Hedef kültüre ait giyinme ve süslenme alışkanlıkları yer alır. & 18 & 11 & 32 & 61 \\
\hline Hedef kültürde aile kurumuna ait bilgiler yer alır. & 10 & 12 & 24 & 46 \\
\hline Hedef kültürde üreme ve cinsel sağlıkla ilgili bilgiler yer alır. & 17 & 17 & 36 & 70 \\
\hline Hedef kültürde eğlence hayatıyla ilgili bilgiler vardır. & 16 & 15 & 29 & 60 \\
\hline Hedef kültürde gelenek, festival ve kutlamalarla ilgili bilgiler yer alır. & 16 & 15 & 33 & 64 \\
\hline Hedef kültüre ait tarihi eser ve bilgiler yer almaktadır. & 17 & 13 & 32 & 62 \\
\hline Hedef kültüre ait coğrafi bilgiler yer almaktadır. & 17 & 10 & 26 & 53 \\
\hline Hedef kültüre ait okul ve eğitim yaşantıları yer almaktadır. & 12 & 13 & 18 & 43 \\
\hline Toplam (f) & 333 & 301 & 604 & 1236 \\
\hline
\end{tabular}

Tablo 9' da "Yabancı Dil Ders Kitaplarında Hedef Kültür Bilgisini incelemede Kullanılabilecek Kontrol Listesi" nin kültürel ögeleri içerme düzeyine yönelik "Kültürel Unsurlar-Ögeler" üçüncü alt boyutuna (hiç) ilişkin bulgulara yer verilmiştir.

Tablo 9'da görüldüğü üzere; B1, B2 ve C1+ düzeylerinde üçüncü alt boyut en çok "Hedef kültüre ait musiki bilgileri yer almaktadır.", "Hedef kültürün spor çalışmaları yer almaktadır." maddelerinde tespit edilmişken, en az "Hedef kültürün diğer kültürden edindiği bilgi ve alışkanlıklar yer alır." maddesinde belirlenmiştir.

Bu bağlamda, B1'de 333, B2'de 301, C1+ düzeyinde 604 kez olmak üzere ikinci alt boyut toplamda 1236 kez tespit edilmiştir.

Özetle, "Yabancılara Türkçe Öğretimi İstanbul Seti"nde (B1, B2, C1+) birinci alt probleme yönelik; okuma metinlerinin isimlerine, bulundukları sayfa numaralarına değinilmiştir. Diğer taraftan, B1 ve B2 düzeylerinde 18, C1+ düzeyinde ise toplam 36 metnin yer aldığı tespit edilmiştir.

"Yabancılara Türkçe Öğretimi İstanbul Seti"nde (B1, B2, C1+) ikinci alt probleme yönelik; okuma metinlerinin, türleri ve türlerinin düzeylere göre dağılımı belirlenmiştir. B1, B2, C1+ düzeylerinde incelenen kitaplarda en fazla bilgilendirici metin türüne, en az ise hikâye edici metin türüne yer 
verildiği görülmektedir. Metinler türlerine göre incelendiğinde, şiirsel metinlere yer verilmediği görülmektedir. B1, B2, C1+ düzeylerinde bilgilendirici metin türlerinden en çok makaleye yer verilmiştir. Bu bağlamda, Yabancilara Türkçe Öğretimi İstanbul Seti"ndeki (B1, B2, C1+) 72 adet okuma metni içerisinde 49 adet bilgilendirici metin, 9 adet hikâye edici metin, 14 adet medya metni tespit edilmiştir.

“Yabancılara Türkçe Öğretimi İstanbul Seti”nde (B1, B2, C1+) üçüncü alt probleme yönelik; okuma metinlerinin, özgünlük/özellik durumları ve özgünlük/özellik durumlarının düzeylere göre dağılımına yer verilmiştir. B1, B2, C1+ düzeyinde yer alan okuma metinlerinde yer alan özel metinlerin toplamı 31, özgün metinlerin toplamı 14, özgün* metinlerin toplamı ise $27^{\prime}$ dir. B1, B2, C1+ düzeyinde yer alan okuma metinlerinin çoğunlukla özel metin olduğu tespit edilmiştir.

“Yabancılara Türkçe Öğretimi İstanbul Seti”nde (B1, B2, C1+) dördüncü alt probleme yönelik; okuma metinlerinde "Yabancı Dil Ders Kitaplarında Hedef Kültür Bilgisini incelemede Kullanılabilecek Kontrol Listesi" nin kültürel ögeleri içerme düzeyine ilişkin "Bakış Açısı", "Kültürel Unsurlar-Ögeler" alt başlıkları değerlendirilmiştir. Genel olarak okuma metinlerinin kültürel ögeleri içerme düzeyi incelendiğinde, "bakış açısı" kontrol listesinin birinci alt boyut (çoğunlukla), ikinci alt boyut (nadiren) ve üçüncü alt boyut (hiç) maddelerinin daha çok "sıklıkla" olarak geçtiği görülmüştür. Okuma metinlerinin kültürel ögeleri içerme düzeyi "kültürel unsurlar/ögeler" kontrol listesinin üçüncü alt boyuta yönelik (hiç) maddelerinin, ikinci alt boyut (nadiren) ve birinci alt boyut (çoğunlukla) maddelerine göre daha çok "sıklıkla" olarak geçtiği görülmüştür. Bu bağlamda, Yabancllara Türkçe Öğretimi İstanbul Seti'nde (B1, B2, C1+) yer alan okuma metinlerinin kültürel ögeleri içerme düzeyinin yetersiz olduğu düşünülmektedir.

\section{Sonuç ve Öneriler}

“İstanbul Yabancılar İçin Türkçe Seti”nde (B1, B2, C1+) yer alan okuma metinlerinin isimlendirilmesi boyutuna yönelik bulgular göz önüne alındığında, B1 düzeyinde 18, B2 düzeyinde 18, C1+ düzeyinde ise 36 okuma metni tespit edilmiştir. İncelenen kitapların tamamında toplam 72 metnin yer aldığ1 görülmektedir (Tablo 2). C1+ düzeyinde kullanılan metinlerin sayı olarak, B1 ve B2 düzeylerinde kullanılan metinlere denk olmamasının sebebinin hem $\mathrm{C} 1$ hem de $\mathrm{C} 2$ düzeylerine yönelik içerikleri kapsamasından kaynaklandığı düşünülmektedir. Bu noktadan hareketle, kitaplardaki metin sayılarının, düzeylere göre dengeli dağılım gösterdiği söylenebilir.

"İstanbul Yabancilar İçin Türkçe Seti”nde (B1, B2, C1+) yer alan okuma metinlerinin, türleri ve türlerinin düzeylere göre dağılımı boyutuna yönelik bulgular göz önüne alındığında, bilgilendirici metinlerin çokluğu dikkat çekmektedir. B1 düzeyinde 11, B2 düzeyinde 13 ve $\mathrm{C} 1+$ düzeyinde 25 bilgilendirici metin tespit edilmiştir. İncelenen kitapların toplamında ise 49 bilgilendirici metin yer almaktadır (Grafik 1). Verilerden elde edilen bilgiler 1şı̆̆ında, "İstanbul Yabancılar İçin Türkçe Seti"nde kullanılan okuma metinlerinde bilgilendirici metinlere ağırlık verildiği ancak şiirsel metinlere yer verilmediği görülmektedir. Metinlerde türlerin orantılı dağılımını sağlamak açısından şiirsel metin türlerinin de kitaplara eklenmesi sağlanabilir. Bu bağlamda, Keklik (2009) öyküleyici ve bilgilendirici metin türlerinin kitaplara orantılı dağıtılması gerekliliğinin önemini vurgulamaktadır.

“İstanbul Yabancılar İçin Türkçe Seti”nde (B1, B2, C1+) yer alan okuma metinlerinin türlere göre dağılımı boyutuna yönelik bulgular incelediğinde ise, bilgilendirici metinlerden en çok makale (17), hikâye edici metinlerden en çok tiyatro (3), medya metinlerinden ise en çok blog yazısına (9) yer verildiği görülmektedir (Grafik 2, 3, 4). Çizgi roman, günlük, fabl, masal, e-posta, şiir gibi farklı türlere 
ise yer verilmediği görülmektedir. Benzer şekilde, Serin ve Turan (2015) Yunus Emre Türkçe Öğretimi Seti'nde yer alan metinlerin tür, tema ve özgünlüklerini incelediği çalışmasında; rapor, masal, eleştiri ve şiir türlerinin ihmal edildiği sonucuna ulaşmış ve kitaplarda farklı türlere yer verilmesinin öğrencilerin yararına olacağını ifade etmiştir.

“İstanbul Yabancılar İçin Türkçe Seti”nde (B1, B2, C1+) yer alan okuma metinlerinin özgünlük/özellik durumları boyutuna yönelik bulgulara bakıldığında, özgün ve düzeltilmiş özgün metin sayısının (41), özel metin (31) sayısına göre daha fazla olduğu görülmektedir (Tablo 3). Kitapların düzeyleri yükseldikçe özel metin sayısının arttığı düşünüldüğünde, düzeyler yükseldikçe özgün metin sayısının da doğru orantılı olarak arttırılması sağlanabilir (Grafik 5 ve Tablo 3). Güneş (2013), günümüz Türkçe öğretimindeki gelişmeler ile birlikte ders kitaplarında klasik sayılabilecek edebi, bilgilendirici metin türlerinin yanında özgün/özel metinlere de yer verilmesinin öğrencilere bilişsel alanda yetkinlik kazandıracağını belirtmektedir.

“İstanbul Yabancllar için Türkçe Seti”nde (B1, B2, C1+) yer alan okuma metinlerinin; kültürel ögeleri içerme boyutuna yönelik bulgular göz önüne alındığında, "Yabancı Dil Ders Kitaplarında Hedef Kültür Bilgisini İncelemede Kullanılabilecek Kontrol Listesi"nde yer alan maddelerin genellikle üçüncü alt boyut (hiç) olarak değerlendirildiği görülmektedir (Tablo 6, Tablo 9). Bu bağlamda, okuma metinlerinin kültürel ögeleri içerme açısından yetersiz olduğu söylenebilir. Bayraktar (2015) benzer şekilde, Yeni Hitit 1 Yabancılar İçin Türkçe Ders Kitabında, ortak (evrensel) kültürün Türk kültürüne oranla daha çok ön plana çıkarıldığını ifade etmektedir. Bu bağlamda, yabancılara Türkçe öğretimi alanında tasarlanacak muhtemel yeni setlerde yer alacak okuma metinlerinde, Türk kültür ve geleneklerine yönelik unsurlara daha çok yer verilmesi önem arz etmektedir.

Vargelen (2013) ise İstanbul Yabancılar İçin Türkçe Ders Kitaplarında yer alan materyalleri değerlendirdiği yüksek lisans çalışmasında, ders kitaplarında Türk kültürüne yönelik unsurların aktarımı konusundaki yetersizliklere değinmiştir. Öneri olarak ise kültüre yönelik ögelerin ders kitaplarında arttırılmasının gerekliliğini vurgulamıştır.

\section{Öneriler}

1. Yabancılar için hazırlanan Türkçe ders kitaplarında, hikâye edici metinlere ve şiirsel metinlere daha çok yer verilebilir.

2. Ayrıca, metin türlerinin tüm düzeylere (A1, A2, B1, B2, C1, C2) daha orantılı bir şekilde dağılması sağlanabilir. Şeçkin Polat ve Dilidüzgün (2015) "Yabancı Dil Olarak Türkçe Öğretiminde Şiir Etkinliklerinin Kültürel İşlevi” adlı çalışmada; ders kitaplarında şiir türüne çok yer verilmediğini ileri seviyelerde yer verilen şiirlerin ise kültürel ögeleri yeterince içermediğini ifade etmektedir.

3. Bilgilendirici metinlerden ise makaleye diğer türlere göre daha çok yer verildiği görülmüsstür. Kitaplarda makale dışındaki metin türlerine de adet ve çeşitlilik bağlamında orantılı şekilde yer verilmesi sağlanabilir.

4. Yabancılara Türkçe öğretmek amacıyla hazırlanan kitaplarda özgün ve özel metinlere orantılı bir şekilde yer verilebilir. Bu bağlamda orijinalliği bozulmamış özgün metinlerin ileri düzeylerde daha fazla yer alması sağlanabilir.

5. Metinlerin, öğrenci düzeylerine göre sadeleştirilmesi/düzenlenmesi sırasında özünü ve orijinalliğini kaybetmemesi hususu göz önünde bulundurulabilir. Kitapların kaynakça kısmında, özellikle özel 
metinler olmak üzere, tüm metinlerin güncel kaynakça bilgisine yer verilmelidir. Bu şekilde, öğrencilerin metin kaynakçalarına istedikleri zaman ulaşımı sağlanabilir.

6. Kitaplardaki okuma metinlerinin Türk kültürünü ve geleneklerini öğretmesi/aktarması açısından yetersiz olduğu sonucundan hareketle, yabancılara Türkçe ders kitaplarında Türk kültürüne yönelik ögelerin okuma metinlerinde daha fazla yer alması sağlanabilir. Demir ve Açı (2011), yabancılara Türkçe öğretiminde kullanılacak metinlerin, öğrencilere verilmek istenen bilgileri ve kültürel değerleri içeren metinlerden seçilmesinin gerekliliğinin altını çizmektedir.

\section{Kaynakça}

Aksan, D. (2015). Her Yönüyle Dil, Ankara: Türk Dil Kurumu Yayınları.

Asutay, H. (2003). Yabancı Dil Öğretiminde Kültür Bağlamı ve Öteki Dil. Ankara Üniversitesi (TÖMER) Dil Dergisi, (118), 26-29.

Avrupa Ortak Başvuru Metni (2015). Avrupa Konseyi. Common European Framework of Reference for Languages: Learning, Teaching, Assessment. Council of Europe.

Barışkan, C. (2010). Türkiye'de Hazırlanan İngilizce Ders Kitapları İle Uluslararası İngilizce Ders Kitapları Arasındaki Kültür Aktarımı Farkları (Yayımlanmamış yüksek lisans tezi). Trakya Üniversitesi/Sosyal Bilimler Enstitüsü, Edirne.

Büyüköztürk, Ş., Kılıç Çakmak, E., Akgün, Ö.E., Karadeniz, Ş. ve Demirel, F. (2015). Bilimsel Araştırma Yöntemleri (19. Baskı), Ankara: Pegem Akademi.

Demir, A, Açık, D. (2011). Türkçenin Yabancı Dil Olarak Öğretiminde Kültürlerarası Yaklaşım Ve Seçilecek Metinlerde Bulunması Gereken Özellikler. Türklük Bilimi Araştırmaları, (30), 51-72.

Demir, D. (2014). Yabancı Dil Olarak Türkçe Öğretim Kitaplarının Kültürel İçeriği. Hacettepe Üniversitesi Yabancı Dil Olarak Türkçe Araştırmaları Dergisi, Yaz (1), 53-61.

Demirel, Ö ve Kıroğlu, K. (2008). Konu Alanı Ders Düzey İncelenmesi, Ankara: Pegem Akademi Yayınları.

Güneş, F. (2017). Dil Öğretiminde Yaklaşımlar ve Modeller, Ankara: Pegem Akademi Yayınları.

Güneş, F. (2013). Türkçe Öğretiminde Metin Seçimi. Ana Dili Eğitimi Dergisi, 1 (1), 1-12.

İstanbul Yabancılar İçin Türkçe Ders Düzey B1. (2016). İstanbul: Kültür Sanat Basımevi.

İstanbul Yabancılar İçin Türkçe Ders Düzey B2. (2016). İstanbul: Kültür Sanat Basımevi.

İstanbul Yabancılar İçin Türkçe Ders Düzey C1+. (2013). İstanbul: Kültür Sanat Basımevi.

Kaplan, M. (1982). Kültür ve Dil, İstanbul: Dergâh yayınları.

Kırkkeseli, Ö. (2017). 8. Sınıf Türkçe Ders Kitabında Yer Alan Şiir ve Okuma Metinlerinin Kültürel Ögeler Açısından Değerlendirilmesi (Yayımlanmamış yüksek lisans tezi). Atatürk Üniversitesi/Eğitim Bilimleri Enstitüsü, Erzurum.

MEB. (2018). Türkçe dersi öğretim programı (İlkokul ve Ortaokul 1, 2, 3, 4, 5, 6, 7 ve 8. Sınıflar). Ankara: MEB Yayınları. 
Okur, A ve Keskin, F. (2013). Yabancılara Türkçe Öğretiminde Kültürel ögelerin Aktarımı: İstanbul Yabancilar İçin Türkçe Öğretim Seti Örneği. The Journal of Academic Social Science Studies (6/2), 1619-1640.

Özmen, Rüya Güzel. “Okuma Becerisi”, Konu Alanı Ders Düzey İnceleme Kılavuzu - Türkçe 1-8, (hzl. Prof. Dr. Ayşegül ATAMAN ve diğerleri), Ankara: Nobel Yayın Dağıtım, 2001.

Saraç, H. S. ve Arıkan, A. (2010). Yabancı Dil Ders Kitaplarında Hedef Kültür Bilgisini İncelemede Kullanılabilecek Kontrol Listesi Uygulaması. Hitit Üniversitesi Sosyal Bilimler Enstitüsü Dergisi, 3(12), 45-56.

Seçkin Polat, Ö. ve Dilidüzgün Ş. (2015). Yabancı Dil Olarak Türkçe Öğretiminde Şiir Etkinliklerinin Kültürel İşlevi. Turkish Studies, 10 (7), 815-834.

Serin, N. ve Turan, E. D. (2015). Yunus Emre Türkçe Öğretimi Setinde Yer Alan Metinlerin Tür, Tema ve Özgünlük Açısından İncelenmesi. Uluslararası Türkçe Edebiyat Kültür Eğitim Dergisi, 4(3), 12291250 .

Tertemiz, N., Ercan, L. ve Kayabaşı, Y. (2011). Ders Düzey ve Eğitimdeki Önemi, L. Küçükahmet (ed.). Konu Alanı Ders Düzey İnceleme Kılavuzu, Ankara: Nobel Yayın Dağıtım.

Tok, M. (2013). Yabancılara Türkçe Öğretimi Ders Kitaplarındaki Yazma Çalışmalarının Değerlendirilmesi. Uşak Üniversitesi Sosyal Bilimler Dergisi Kış (6/1), 249-279.

Yıldırım, A. ve Şimşek, H. (2018). Sosyal Bilimlerde Nitel Araştırma Yöntemleri (11. Baskı), İstanbul: Seçkin.

Vargelen, H. (2013). Kültürler Arası İletişimsel Yeterlilik Bağlamında Yabancı Dil Olarak Türkçe Öğretimi Ders Kitaplarının Değerlendirilmesi (Yayımlanmamış yüksek lisans tezi). Gazi Üniversitesi/Eğitim Bilimleri Enstitüsü, Ankara.

Keklik, S. (2009). 1-8. Sınıf Türkçe Dersi Ders Kitaplarının Metin Türleri Ve Özellikleri Açısından İncelenmesi. I. Uluslararası Türkiye Eğitim Araştırmaları Kongresi. https://docplayer.biz.tr/7580284-18-sinif-turkce-dersi-ders-kitaplarinin-metin-turleri-ve-ozellikleri-acisindan-incelenmesi-saadettinkeklik-1-ozet.html\#download_tab_content. Erişim Tarihi: 08.05.2019.

Türk Dil Kurumu (2019). Türkçe Sözlük.

http://www.tdk.gov.tr/index.php?option=com_gts\&arama=gts\&guid=TDK.GTS.5ccef0b7b7ea98.09103 049. Erişim Tarihi: 05.05.2019. 